University of Nebraska - Lincoln

DigitalCommons@University of Nebraska - Lincoln

\title{
Nutrient composition of selected traditional United States Northern Plains Native American plant foods
}

\author{
Katherine M. Phillips \\ Virginia Tech \\ Pamela R. Pehrsson \\ USDA, ARS Nutrient Data Laboratory, pamela.pehrsson@ars.usda.gov \\ Wanda W. Agnew \\ United Tribes Technical College \\ Angela J. Scheett \\ USDA, ARS Grand Forks Human Nutrition Research Center \\ Jennifer R. Follett \\ USDA, ARS Grand Forks Human Nutrition Research Center \\ See next page for additional authors
}

Follow this and additional works at: https://digitalcommons.unl.edu/usdaarsfacpub

Phillips, Katherine M.; Pehrsson, Pamela R.; Agnew, Wanda W.; Scheett, Angela J.; Follett, Jennifer R.; Lukaski, Henry C.; and Patterson, Kristine Y., "Nutrient composition of selected traditional United States Northern Plains Native American plant foods" (2014). Publications from USDA-ARS / UNL Faculty. 1470. https://digitalcommons.unl.edu/usdaarsfacpub/1470

This Article is brought to you for free and open access by the U.S. Department of Agriculture: Agricultural Research Service, Lincoln, Nebraska at DigitalCommons@University of Nebraska - Lincoln. It has been accepted for inclusion in Publications from USDA-ARS / UNL Faculty by an authorized administrator of DigitalCommons@University of Nebraska - Lincoln. 


\section{Authors}

Katherine M. Phillips, Pamela R. Pehrsson, Wanda W. Agnew, Angela J. Scheett, Jennifer R. Follett, Henry C. Lukaski, and Kristine Y. Patterson 


\title{
Nutrient composition of selected traditional United States Northern Plains Native American plant foods ${ }^{\text {负, 位说 }}$
}

\author{
Katherine M. Phillips ${ }^{a}$, Pamela R. Pehrsson ${ }^{\text {b,*, Wanda W. Agnew }}{ }^{c}$, Angela J. Scheett ${ }^{\mathrm{d}}$, \\ Jennifer R. Follett ${ }^{\mathrm{d}}$, Henry C. Lukaski ${ }^{\mathrm{d}}$, Kristine Y. Patterson ${ }^{\mathrm{b}}$ \\ a Department of Biochemistry, Virginia Tech, Blacksburg, VA, USA \\ ${ }^{\mathrm{b}}$ USDA, ARS Nutrient Data Laboratory, Beltsville, MD, USA \\ ${ }^{\mathrm{c}}$ United Tribes Technical College, Bismarck, ND, USA \\ ${ }^{\mathrm{d}}$ USDA, ARS Grand Forks Human Nutrition Research Center, Grand Forks, ND, USA
}

\section{A R T I C L E IN F O}

\section{Article history:}

Received 12 August 2013

Received in revised form 5 February 2014

Accepted 6 February 2014

\section{Keywords:}

Food composition

Food analysis

Native American diet

Indigenous food system

Biodiversity and nutrition

Wild food

Foraged food

Chokecherry

Chenopodium album $\mathrm{L}$.

Wild raspberry

Psoralea esculenta Pursh.

Urtica dioica L.

Rosa pratincola Greene

Ascorbic acid

Folate vitamers

Vegetables

Fruits

\begin{abstract}
A B S T R A C T
Ten wild plants (cattail broad leaf shoots, chokecherries, beaked hazelnuts, lambsquarters, plains prickly pear, prairie turnips, stinging nettles, wild plums, raspberries, and rose hips) from three Native American reservations in North Dakota were analyzed to expand composition information of traditional foraged plants. Proximates, dietary fiber (DF), vitamins, minerals, carotenoids, and folate vitamers were assayed using standard methods and reference materials. Per serving, all were rich in $\mathrm{Mn}(100-2808 \mu \mathrm{g})$. Several provided $>10 \%$ DRI of Fe (cattail shoots, steamed lambsquarters, and prairie turnips), Ca (steamed lambsquarters, prickly pear, and prairie turnips), Mg (cattail shoots, lambsquarters, prickly pear, and prairie turnips), vitamins B6 (chokecherries, steamed lambsquarters, broiled prickly pear, and prairie turnips), C (raw prickly pear, plums, raspberries, rose hips $(426 \mathrm{mg} / 100 \mathrm{~g}$ ), and $\mathrm{K}$ (cattail shoots, chokecherries, lambsquarters, plums, rose hips, and stinging nettles). DF was $>10 \mathrm{~g} / \mathrm{serving}$ in chokecherries, prairie turnips, plums and raspberries. Rose hips, plums, lambsquarters, and stinging nettles were carotenoid-rich (total, 3.2-11.7 mg/100 g; $\beta$-carotene, $1.2-2.4 \mathrm{mg} / 100 \mathrm{~g}$; lutein/zeaxanthin, $0.9-6.2 \mathrm{mg} / 100 \mathrm{~g}$ ) and lycopene (rose hips only, $6.8 \mathrm{mg} / 100 \mathrm{~g}$ ). Folate (primarily 5-methyltetrahydrofolate) was highest in raw lambsquarters $(97.5 \mu \mathrm{g} / 100 \mathrm{~g})$ and notable in cattail shoots, raw prairie turnips, and blanched stinging nettles $(10.8,11.5$, and $24.0 \mu \mathrm{g} / 100 \mathrm{~g}$, respectively). Results, provided to collaborating tribes and available in the National Nutrient Database of the United States Department of Agriculture (USDA) (www.ars.usda.gov/nutrientdata), support reintroduction or increased consumption of foraged plants.
\end{abstract}

() 2014 Published by Elsevier Inc.

\section{Introduction}

The diets and nutrient intakes of Native Americans have changed over time. From the 1800s until the 1970s, the fundamental nutritional concern of Native people was a lack of

\footnotetext{
Mention of a trademark or proprietary product does not constitute a guarantee of the product by the United States Department of Agriculture and does not imply its approval to the exclusion of other products that may also be suitable.

US Department of Agriculture, Agricultural Research, Northern Plains Area is an equal opportunity/affirmative action employer and all agency services are available without discrimination.

* Corresponding author at: USDA, ARS Nutrient Data Laboratory, 10300 Baltimore Avenue, Building 005, Room 208A, Beltsville, MD 20705, USA. Tel.: +1 301504 0630; fax: +1 3015040632 .

E-mail address: pamela.pehrsson@ars.usda.gov (P.R. Pehrsson).
}

adequate food (Story et al., 1998). The composition of the traditional diet of Native Americans has changed gradually, with increased intakes of fat and decreased consumption of harvested plant foods (Byers, 1996). Traditional foods of Native Americans (American Indians and Alaska Natives), largely influenced by climate, geography and tribal mobility, are specific to each Native American nation tribe. Fishing, hunting, harvesting and to some extent, agriculture, permitted the tribes to make the best use of indigenous resources. Also specific to the tribes are ceremonial dishes and everyday dishes, where cultural and/or spiritual meaning is very important (Kittler and Sucher, 2001).

Currently, traditional foods and particularly plant foods are not being eaten on a regular basis. A 2002 survey found that fewer than $10 \%$ of Native American children consumed traditional foods (Lytle et al., 2002). Moreover, among the foods actually being eaten at 
present, only 7 of the more than 1300 foods listed were identified as traditional. Surveys have shown that Native Americans regard traditional foods as health-promoting (Powers and Powers, 1990), but these foods are usually consumed only at special ceremonies and celebratory events (Bass and Wakefield, 1974; deGonzague et al., 1999; Toma and Curry, 1980; Woolf et al., 1999; Zephier et al., 1997).

The under-nutrition among Native Americans prevalent in the 1970 s has been replaced by over-nutrition, in which contemporary food products, which are low in micronutrients (vitamins and minerals) but high in energy content (particularly fat) and are known to promote obesity, predominate (Lytle et al., 2002; Stang et al., 2005; Story et al., 1998; Taylor et al., 2005; Zephier et al., 1997). Studies of dietary intakes of Native Americans in Arizona, North Carolina, North and South Dakota, and Oklahoma found that vitamin and mineral intake fell under the recommended levels, but that fat consumption exceeded what is recommended in health guidelines, at $>35 \%$ of daily energy intake (deGonzague et al., 1999; Zephier et al., 1997).

Many plant foods are rich in health-promoting components, including vitamins, minerals, and other bioactive factors, and have low fat and high fiber contents. It is likely that promoting consumption of traditional Native American foods could improve nutrition in these populations (Burns Kraft et al., 2008); however, there is a paucity of information on the nutrient contents of these plant foods, particularly the ones traditionally consumed among tribes in the Northern Plains (Schauss, 2010; Woolf et al., 1999). Nutrient composition data for these foods are needed to develop nutrient databases that support both practical and research applications that rely on food composition data (Amy and Pehrsson, 2003; Ershow, 2003; Pennington, 2003), to increase knowledge of biodiversity in food composition (Burlingame et al., 2009), and to facilitate health intervention research and programming.

Although some reports exist on some of the nutrients in a few of the foods (e.g. Andersson et al., 2011; Bhargava et al., 2008; Guil et al., 1997; Guil-Guerrero et al., 2003; Kuhnlein, 1990; Yildirim et al., 2001), without common control samples between studies it is impossible to compare nutrient concentrations because interlaboratory analytical uncertainty could be confused with a true difference in composition (Phillips et al., 2006a). Additionally, different growing conditions can affect the concentration of nutrients in the same plant species (Bhargava et al., 2008; Pennington, 2008). Biodiversity of food composition is of increasing interest for sustainable food supplies (Burlingame et al., 2009; Charrondière et al., 2013; Heywood, 2011; Toledo and Burlingame, 2006).

This study focused on determining the nutrient composition of ten traditional wild plant foods collected in season by Native American tribes from reservations in the Northern Plains region of the US, as part of the US Department of Agriculture (USDA) National Food and Nutrient Analysis Program (Haytowitz et al., 2008), with detailed quality control including analysis of commercially available reference materials, to increase data on the composition of traditional Native American foods (Amy and Pehrsson, 2003).

\section{Materials and methods}

\subsection{Samples}

Staff from United Tribes Technical College (UTTC) (Bismarck, ND, USA) contacted tribal leaders and elders of the Turtle Mountain Band of Chippewa (Belcourt, ND, USA), three affiliated tribes of Ft. Berthold, ND (Mandan, Hidatsa, Arikara), and Standing Rock Sioux reservation (ND) and received permission for participation in this study. UTTC staff accompanied selected tribal elders who collected traditional plant foods: prairie turnips (Psoralea esculenta Pursh.), lambsquarters (Chenopodium album L.), cattail broad leaf shoots (Typha latifolia L.), stinging nettles (Urtica dioica L.), wild plums (Prunus americana Marshall), chokecherries (Prunus virginiana L.), wild rose hips (Rosa pratincola Greene), wild raspberries (Rubus idaeus L.), beaked hazelnuts (Corylus cornuta Marshall), and plains prickly pears (Opuntia polyacantha Haw.) in a culturally respectful manner in 2005 during the typical foraging season (May and June) at each of the three reservations located as indicated in Fig. 1. A late frost and other impediments to optimal growing conditions limited the number and amounts of plant foods that were available for collection; therefore, a total of $0.5-2 \mathrm{~kg}$ of each plant was sampled. The total amount comprised one sample for each food except prairie turnips (2 samples), chokecherries (3 samples), stinging nettles (2 samples), cattail shoots (3 samples), and lambsquarters

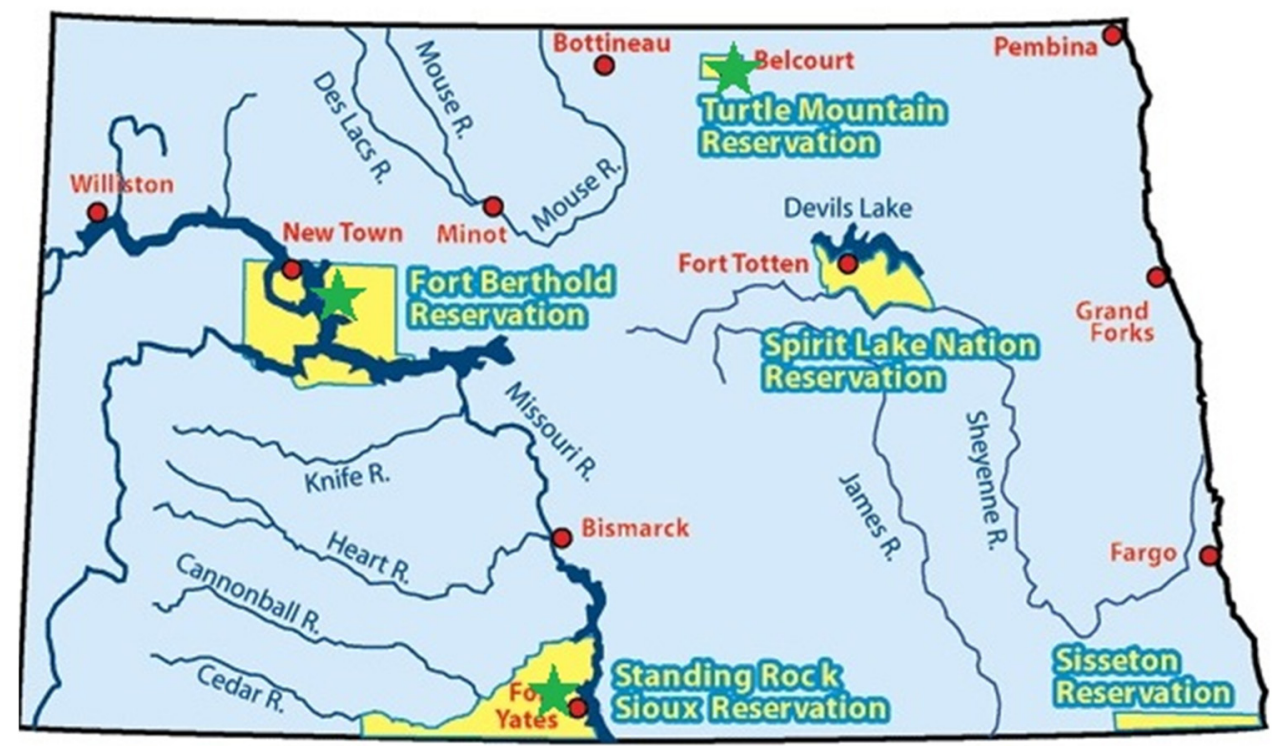

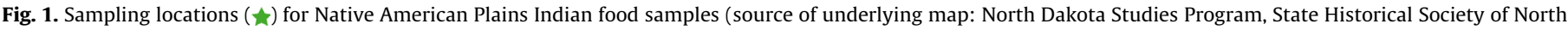
Dakota, http://www.ndstudies.org/images/aind/reservations.gif). 
(2 samples), with a "sample" being the material collected from a given location on a given day. Each sample was homogenized and subsampled for analysis, except for lambsquarters where the two samples were composited, and cattails shoots where two of the samples were combined for analysis and the third was analyzed individually.

Plant species were identified as closely as possible by horticulturalists in the UTTC Extension Department using information from the sample gathering log sheets and photographs of the collected plant material, including consideration of sampling locations, compared to entries in a reference manual on native regional plants (Gilmore, 1991) and the USDA PLANTS database (USDA Natural Resource Conservation Service, 2013).

The plant samples were shipped with overnight delivery to the Food Analysis Laboratory Control Center (FALCC) at Virginia Tech (Virginia Polytechnic Institute and State University, Blacksburg, VA, USA), taking care to ensure the integrity and preservation of nutrients in the samples, as previously reported (Trainer et al., 2010). The beaked hazelnuts and the rinsed wild raspberries and chokecherries were frozen prior to shipment and shipped frozen; all other samples were shipped at refrigerated temperature using cold packs. Upon receipt at Virginia Tech, samples were inspected to ensure integrity of packaging. Refrigerated samples were stored at $2-5{ }^{\circ} \mathrm{C}$ and prepared within 4 days of receipt. Frozen samples were stored at -12 to $-15{ }^{\circ} \mathrm{C}$ and prepared within 9 days of receipt, except beaked hazelnuts which were held frozen 5 months. Most products were analyzed raw; cooked plants were processed by methods specified by tribal elders.

\subsection{Sample preparation}

For each food, samples or composites of samples (Section 2.1) were homogenized and dispensed into subsamples for analysis. Most products were analyzed raw; cooked plants were processed by methods specified by tribal elders.

For each food the sample material to be included was cleaned and the inedible portion was removed just before homogenization. First, the material was rinsed thoroughly for 1-2 min with tap water, then 1 min with distilled deionized (DDI) water, and then patted dry with a clean, lint-free cloth. Inedible portions were as follows: damaged or discolored areas from stinging nettles, lambsquarters, and cattail broad leaf shoots; roots from the lambsquarters and cattail broad leaf shoots; stems, leaves, and pits from wild plums; twigs and leaves from wild raspberries and chokecherries; stems and leaves from wild rose hips; bark and roots from prairie turnips; shells from beaked hazelnuts; needles and tough, outer layer of paddles from plains prickly pear; any seeds from lambsquarters. Plains prickly pear was broiled $23 \mathrm{~cm}$ from a pre-heated broiler for $9 \mathrm{~min}$. Stinging nettles were blanched by boiling in DDI water for $1 \mathrm{~min}$ and then draining in a colander. Prairie turnips were boiled in DDI water until tender ( $\sim 15 \mathrm{~min})$. Lambsquarters were steamed over boiling water for $8 \mathrm{~min}$. All cooking was carried out using stainless steel pots.

The prepared samples for each composite were cut into approximately $1 \mathrm{~cm}$ pieces, immediately frozen in liquid nitrogen, and homogenized to a fine powder using a 6L stainless steel industrial food processor (Robot Coupe 6L Blixer; Robot Coupe USA, Jackson, MS) while kept frozen in liquid nitrogen, accomplished with a total of approximately 1 min grinding time in 30-s intervals after an initial 10-s pulse. Subsamples (12-15 g) of the material were dispensed, while still frozen in liquid nitrogen, among 60-mL straight-side glass jars with Teflon ${ }^{\mathrm{TM}}$ lined lids and sealed under residual nitrogen. The the jars were wrapped with aluminum foil and stored at $-60 \pm 3{ }^{\circ} \mathrm{C}$ until analyzed.

\subsection{Analytical methods}

Macronutrients, vitamins, and minerals, carotenoids, and folate vitamers were assayed. Standard and/or published methods were used, consistent with the methods of analysis for other foods in the USDA National Food and Nutrient Analysis Program (NFNAP) (Haytowitz et al., 2008). Table 1 summarizes methods used for determination of proximate composition, niacin, pantothenic acid, riboflavin, thiamin, vitamin B6, vitamin C, macro- and traceelements (Covance Laboratories, Madison, WI, except for beaked hazelnuts which were analyzed at Silliker Inc., Crete, IL), vitamin K (USDA-HNRCA Laboratory, Tufts University, Boston, MA), choline (University of North Carolina, Chapel Hill, NC), and folate vitamers (Food Analysis Laboratory Control Center, Virginia Tech, Blacksburg, VA).

Carotenoids were analyzed at Craft Technologies Inc. (Wilson, NC) by reversed-phase HPLC with UV-vis detection using published methodology (Craft, 2001). The HPLC system consisted of a solvent degasser, gradient pump, temperature controlled autosampler, and programmable UV-vis detector (Thermo Separation Products, San Jose, CA). The column was a Spherisorb ODS2, $250 \mathrm{~mm} \times 4.0 \mathrm{~mm}, 3 \mu$ with titanium frits (ES Industries, West Berlin, $\mathrm{NJ}$ ), and the mobile phase was $800 \mathrm{~mL}$ acetonitrile, $150 \mathrm{~mL}$ p-dioxane, $50 \mathrm{~mL}$ methanol:isopropanol (50:50) containing $150 \mathrm{mM}$ ammonium acetate and $1 \mathrm{~mL}$ triethylamine, with flow rate of $1.0 \mathrm{~mL} / \mathrm{min}$. Briefly, samples were evaluated with regard to their matrix for chlorophylls or esterified carotenoids and saponified if necessary before extraction. Extracts were diluted in mobile phase and $15 \mu \mathrm{L}$ was injected for HPLC. Carotenoids were detected at $450 \mathrm{~nm}$ and peaks were identified by coelution with authentic standards, and in some cases with diode array detection. The method was calibrated with neat standards that were assigned concentrations determined using molar extinction coefficients and correction for HPLC purity, and analytes were quantified based on external standards using peak areas.

Samples of well-characterized control composites (CC) with established tolerance limits developed for the NFNAP (Phillips et al., 2006a) and/or certified reference materials (CRMs) were included in each analytical run to validate results, as described previously (Phillips et al., 2006a, 2007). CRMs were obtained from the National Institute of Standards and Technology (NIST, Gaithersburg, MD) (SRM ${ }^{\mathbb{}} 2383$ Babyfood, SRM ${ }^{\mathbb{R}} 2387$ Peanut Butter) and the Institute of Reference Materials and Methods (Geel, Belgium; purchased from RT Corp., Laramie, WY) (CRM 485 Lyophilized Mixed Vegetables, CRM 431 Lyophilized Brussels Sprouts).

\subsection{Data analysis}

Results for the CCs and CRMs analyzed with the samples were compared to the certified ranges (for the CRM) and to established in-house tolerance limits (for the CC) to validate the accuracy of the measurements (Phillips et al., 2006a). The limited availability of sampling locations and harvested material allowed only a single analytical value for most foods; therefore, the precision (relative standard deviation, RSD) of inter-day results for these materials analyzed at the same laboratory were used to estimate precision of a value in the case of single analysis of a given nutrient/food. When samples of a food from multiple locations were analyzed, data are reported as the mean of the values from all locations (e.g. the three reservations), and the range is given for reference. This action fulfilled the agreement with the tribes that specific nutrient information would not be reported by location.

Nutrient concentrations are reported on a per $100 \mathrm{~g}$ freshweight basis and are also discussed per serving and as a percent of 
Table 1

Analytical methods.

\begin{tabular}{|c|c|c|c|}
\hline Analyte & Method $^{\mathrm{a}}$ & Method description & $\begin{array}{l}\text { Reference citation for meth- } \\
\text { od details }\end{array}$ \\
\hline Moisture & Pressure drying & Sample $(5-10 \mathrm{~g})$ dried under pressure at $70^{\circ} \mathrm{C}$ for $6 \mathrm{~h}$ & $\begin{array}{l}\text { AOAC (2011), method } 934.06 \\
(37.1 .10) \text { Moisture in dried } \\
\text { fruits }\end{array}$ \\
\hline Protein & $\begin{array}{l}\text { Combustion determination } \\
\text { of nitrogen }\end{array}$ & $\begin{array}{l}\text { Nitrogen determined by a combustion-detection technique (Dumas } \\
\text { method), with the percent nitrogen converted to protein using a } \\
\text { factor of } 6.25\end{array}$ & $\begin{array}{l}\text { AOAC (2011), method } 968.06 \\
(4.2 .04), \text { Protein (crude) in } \\
\text { animal feed }\end{array}$ \\
\hline Fat & Acid hydrolysis & $\begin{array}{l}\text { Total fat determined gravimetrically after acid hydrolysis and } \\
\text { recovery of extractable fat using ether and hexane }\end{array}$ & $\begin{array}{l}\text { AOAC (2011), method } 954.02 \\
\text { (4.5.02 or } 7.063) \text { Fat (crude) or } \\
\text { ether extract in pet food }\end{array}$ \\
\hline Dietary fiber & Enzymatic-gravimetric & $\begin{array}{l}\text { Duplicate samples digested with enzymes in a phosphate buffer, } \\
\text { precipitation of soluble fiber with ethanol, followed by gravimetric } \\
\text { determination of fiber in residue corrected for protein and ash } \\
\text { content }\end{array}$ & $\begin{array}{l}\text { AOAC (2011), method } 991.43 \\
\text { (32.1.17) Total, soluble, and } \\
\text { insoluble dietary fiber in foods }\end{array}$ \\
\hline Folate vitamers & $\begin{array}{l}\text { LC-MS spectrometry, after } \\
\text { trienzyme extraction }\end{array}$ & $\begin{array}{l}\text { Tri-enzyme extraction of sample, isolation of folates by solid-phase } \\
\text { extraction, and quantification of individual folate vitamers by LC-MS. } \\
\text { Total folate calculated as the sum of molar equivalent concentrations } \\
\text { of } 5 \text {-methyltetrahydrofolate, } 10 \text {-formylfolic acid, and 5- } \\
\text { formyltetrahydrofolate }\end{array}$ & Phillips et al. (2006b) \\
\hline Niacin & Microbiological & $\begin{array}{l}\text { Sample hydrolyzed with sulfuric acid; pH adjusted to remove } \\
\text { interferences. Niacin determined by comparing the growth response } \\
\text { Lactobacillus plantarum using the sample compared to the growth } \\
\text { response for a niacin standard, measured turbidimetrically }\end{array}$ & $\begin{array}{l}\text { AOAC (2011), methods } \\
944.13 \text { (45.2.04), } 960.46 \\
(45.2 .01), \text { and } 985.34 \\
\text { (50.1.19), Niacin in foods }\end{array}$ \\
\hline Pantothenic acid & Microbiological & $\begin{array}{l}\text { Sample treated with an enzyme mixture to liberate pantothenic acid } \\
\text { from co-enzyme A; pH adjusted to remove interferences. Pantothenic } \\
\text { acid determined by comparing the growth response of Lactobacillus } \\
\text { plantarum using the sample compared to the growth response for a } \\
\text { calcium pantothenate standard, measured turbidimetrically }\end{array}$ & $\begin{array}{l}\text { USP (1995), AOAC (2011), } \\
\text { methods } 945.74(45.2 .05) \\
\text { and } 960.46 \text { (45.2.01), } \\
\text { Pantothenic acid in foods }\end{array}$ \\
\hline Vitamin B6 & Microbiological & $\begin{array}{l}\text { Sample hydrolyzed with dilute sulfuric acid in an autoclave; } \mathrm{pH} \\
\text { adjusted to remove interferences. Vitamin B6 determined by } \\
\text { comparing the growth response of Saccharomyces carlsbergenesis } \\
\text { using the sample compared the growth response for a vitamin B6 } \\
\text { standard, measured turbidimetrically }\end{array}$ & $\begin{array}{l}\text { AOAC (2011), method } 961.15 \\
\text { (45.2.08), Vitamin B6 } \\
\text { (pyridoxine, pyridoxal, and } \\
\text { pyridoxamine) in food extracts }\end{array}$ \\
\hline Riboflavin & Microbiological & $\begin{array}{l}\text { Sample hydrolyzed with dilute hydrochloric acid }(\mathrm{HCl}) ; \mathrm{pH} \text { adjusted } \\
\text { to remove interferences. Riboflavin determined by comparing the } \\
\text { growth response of Lactobacillus casei using the sample compared to } \\
\text { the growth response for a riboflavin standard, measured } \\
\text { turbidimetrically }\end{array}$ & $\begin{array}{l}\text { AOAC (2011), } 940.33 \\
(45.2 .06) \text { riboflavin (Vitamin } \\
\text { B2) in vitamin preparations }\end{array}$ \\
\hline Riboflavin & Fluorometric & $\begin{array}{l}\text { Sample autoclaved in dilute acid; } \mathrm{pH} \text { adjusted with } \mathrm{NaOH} \text {. Dilute } \mathrm{HCl} \\
\text { added to precipitate protein and the sample is filtered. Acetic acid and } \\
\text { then } 4 \% \text { potassium permanganate are added. Hydrogen peroxide is } \\
\text { added to destroy the permanganate color. Fluorescence is measured, } \\
\mathrm{Na}_{2} \mathrm{~S}_{2} \mathrm{O}_{4} \text { added and fluorescence is measured again }\end{array}$ & $\begin{array}{l}\text { AOAC (2011), method } 970.65 \text {, } \\
\text { Riboflavin (vitamin B2) in } \\
\text { foods and vitamin preparations }\end{array}$ \\
\hline Thiamin & Fluorometric & $\begin{array}{l}\text { Sample autoclaved in dilute acid to extract thiamin. Resulting } \\
\text { solution incubated with a buffered enzyme solution to release bound } \\
\text { thiamin. Solution purified on an ion-exchange column. Aliquot taken } \\
\text { and reacted with potassium ferricyanide to convert thiamin to } \\
\text { thiochrome. Thiochrome extracted into isobutyl alcohol and read on a } \\
\text { fluorometer against a known standard }\end{array}$ & $\begin{array}{l}\text { AOAC (2011), methods } \\
942.23 \text { (45.2.05), } 953.17 \\
(45.1 .06), \text { and } 957.17 \\
\text { (45.1.07), Thiamine in bread }\end{array}$ \\
\hline Vitamin C & HPLC & $\begin{array}{l}\text { Vitamin C assayed as total ascorbic acid. Sample extracted with } 5 \% \\
\text { metaphosphoric acid buffer (pH 1.8); dehydroascorbic acid reduced } \\
\text { with TCEP. Ascorbic acid quantified by reverse-phase HPLC with UV } \\
\text { detection at } 254 \mathrm{~nm} \text {, using calibration with external standards }\end{array}$ & Tarrago-Trani et al. (2012) \\
\hline Vitamin $\mathrm{K}$ & HPLC & $\begin{array}{l}\text { Samples extracted with hexane extraction and purified by solid phase } \\
\text { extraction on silica columns. Phylloquinone content determined by } \\
\text { reversed-phase high-performance liquid chromatography (HPLC) } \\
\text { followed by fluorescence detection, with } K_{1(25)} \text { as an internal standard }\end{array}$ & Booth and Sadowsi (1997) \\
\hline Choline & LC/ESI/IDMS & $\begin{array}{l}\text { Samples spiked with deuterium-labeled internal standards of the } \\
\text { different forms of choline. Choline compounds partitioned into } \\
\text { aqueous and non-aqueous solvents and analyzed directly by liquid } \\
\text { chromatography/electrospray ionization-isotope dilution mass } \\
\text { spectrometry }\end{array}$ & Koc et al. (2002) \\
\hline $\begin{array}{l}\text { Elements (Ca, Mg, K, } \\
\quad \mathrm{Na}, \mathrm{P}, \mathrm{Cu}, \mathrm{Fe}, \mathrm{Mn}, \mathrm{Zn})\end{array}$ & ICP & $\begin{array}{l}\text { Dry ashing }\left(500^{\circ} \mathrm{C} \pm 50^{\circ} \mathrm{C}\right) \text { and dissolution in concentrated } \mathrm{HCl} \text {, or wet } \\
\text { ashing (digestion in concentrated acid, with heat) of sample. Followed } \\
\text { by appropriate dilution, followed by quantitation of each element using } \\
\text { an ICP spectrometer and comparing the emission of the unknown } \\
\text { sample against the emission of each element in standard solutions }\end{array}$ & $\begin{array}{l}\text { AOAC (2011), methods } \\
985.01(3.2 .06) \text { and } 984.27 \\
(50.1 .15), \text { Metals in food by ICP }\end{array}$ \\
\hline Selenium & ID-GC-MS & $\begin{array}{l}\text { Digestion of sample using nitric acid, orthophosphoric acid, and } \\
\text { hydrogen peroxide and the formation of } 5 \text {-nitropiazselenol. Samples } \\
\text { spiked with enriched }{ }^{82} \mathrm{Se} \text { and the isotopic ratio of }{ }^{82} \mathrm{Se} \text { to }{ }^{80} \mathrm{Se} \text { is } \\
\text { measured by GC-MS using dual ion monitoring }\end{array}$ & Reamer and Veillon (1981) \\
\hline
\end{tabular}

\footnotetext{
a ESI, electrospray ionization; GC, gas chromatography; HPLC, high performance liquid chromatography; ICP, inductively coupled plasma emission spectroscopy; ID, isotope dilution; LC, liquid chromatography; MS, mass spectrometry; TCEP, tris(2-carboxyethyl)phosphine.
} 
Table 2

Traditional Native American and comparable contemporary plant foods and serving sizes (see Table 3 for further description of the Native American plants).

\begin{tabular}{|c|c|c|c|c|c|c|c|}
\hline \multicolumn{3}{|c|}{ Traditional Native American food } & \multicolumn{3}{|c|}{ Comparable contemporary food } & \multicolumn{2}{|c|}{$\begin{array}{l}\text { Suggested } \\
\text { serving size }\end{array}$} \\
\hline Common name & Scientific name & NDB no. ${ }^{a}$ & Common name & Scientific name & NDB no. ${ }^{a}$ & Volume $^{\mathrm{b}}$ & Grams \\
\hline $\begin{array}{l}\text { Cattail broad leaf shoots, } \\
\text { steamed }\end{array}$ & Typha latifolia L. & 35195 & Asparagus, boiled & Asparagacea officinalis & 11012 & $1 / 2$ cup & 90 \\
\hline Chokecherries & Prunus virginiana $\mathrm{L}$. & 35204 & Gooseberries & Ribes spp. & 09107 & $1 / 2$ cup & 75 \\
\hline Hazelnuts, beaked & Corylus cornuta Marshall & 35233 & Hazelnuts & Corylus spp. & 12120 & $1 / 2$ cup & 25.4 \\
\hline Lambsquarters, raw & Chenopodium album L. & 11244 & Spinach, raw & Spinacia oleracea & 11457 & $1 \mathrm{oz}$. & 30 \\
\hline Lambsquarters, steamed & Chenopodium album $\mathrm{L}$. & 35197 & Spinach, boiled & Spinacia oleracea & 11458 & 2 cups & 180 \\
\hline Plains pricklypear, raw & Opuntia polyacantha Haw. & 35198 & Apple, raw & Malus domestica & 09003 & 1 cup & 149 \\
\hline Plains pricklypear, broiled & Opuntia polyacantha Haw. & 35199 & Apple, microwaved & Malus domestica & 09006 & 1 cup & 115 \\
\hline Prairie turnips, raw & Psoralea esculenta Pursh. & 35200 & Turnips, raw & Brassica rapa (Rapiferagroup) & 11564 & $1 / 2$ cup & 130 \\
\hline Prairie turnips, boiled & Psoralea esculenta Pursh. & 35201 & Turnips, boiled & Brassica rapa (Rapifera group) & 11565 & 1 cup & 156 \\
\hline Stinging nettles, blanched & Urtica dioica $\mathrm{L}$. & 35205 & Peppermint leaves & $\begin{array}{l}\text { Mentha } \times \text { piperita L. nothosubsp. } \\
\text { Piperita }\end{array}$ & 02064 & 1 cup & 20 \\
\hline Wild plums & Prunus americana Marshall & 35206 & Plums & Prunus spp. & 09279 & $1 / 2$ cup & 132 \\
\hline Wild raspberries & Rubus idaeus L. & 35202 & Raspberries & Rubus spp. & 09302 & 2 large & 61.5 \\
\hline Wild rose hips ${ }^{c}$ & Rosa pratincola Greene & 35203 & Cranberries & Vaccinium macrocarpon & 09078 & $1 / 2$ cup & 48 \\
\hline
\end{tabular}

a Database entry number, USDA Nutrient Database for Standard Reference (USDA, 2011).

b 1 cup $=237 \mathrm{~mL}$.

c Also known as prairie rose (Rosa arkansana Porter var. suffulta (Greene) Cockerell) (USDA Natural Resources Conservation Service, 2013).

the Dietary Reference Intake (DRI) (Institute of Medicine (IOM), 1997, 1998, 2000, 2001, 2002, 2004, 2011) and compared to the concentrations in similar contemporary foods to facilitate consideration in the context of food choice recommendations to promote health. Contemporary foods considered as comparable in proximate composition and key minerals and vitamins were used for comparison; in some cases, wild and domesticated versions of the same plant type (e.g. wild and domestic plums) were used when available. However, there were some differences in key components, e.g. moisture content. "Fresh weight" was the edible portion, as prepared for analysis. Traditional and contemporary foods were matched based on similarity of type or use (e.g. type: cattail broad leaf shoots versus asparagus; use: served in tea form, such as stinging nettle versus peppermint leaves). Standard serving sizes and data for the contemporary foods were obtained from the USDA National Nutrient Database for Standard Reference, Release 21 (USDA, 2011). The traditional foods analyzed, the corresponding contemporary foods, and serving sizes are given in Table 2.

\section{Results and discussion}

\subsection{Composition of the traditional Native American foods}

Photographs of the samples of each food collected are shown in Table 3, along with a description of typical preparation and use of the traditional foods. The assayed proximate composition and concentrations of selected elements, vitamins, carotenoids, and folate are shown in Tables 3-7, along with results for the corresponding quality control sample(s) analyzed and the adult DRI for each nutrient. For standardization of data, the assayed nutrient concentrations have been given on a per $100 \mathrm{~g}$ fresh weight basis, but the discussion focuses on the nutrient content per typical serving size (Table 2) to enable meaningful evaluation of the contribution of the food to daily intake. For brevity, \% DRI in the discussion refers to the male DRI only. Nutrient values are shown as the mean based on analysis of the composite sample, and, in cases where more than one composite of a food was analyzed, the range is shown as an indicator of sample-to-sample variability. The mean and inter-day relative standard deviations for the matrixmatched RM and/or CC assayed along with the foods are also included for each nutrient reported.

\subsubsection{Proximate composition}

The results of proximate analyses are summarized in Table 4. Fat content was significant in the beaked hazelnuts $(53 \mathrm{~g} / 100 \mathrm{~g}$; $13.5 \mathrm{~g} /$ serving) and negligible ( $<2 \mathrm{~g} / 100 \mathrm{~g}$ or $<0.1 \mathrm{~g} /$ serving $)$ in the other foods. Steamed lambsquarters had the highest protein content $(7.3 \mathrm{~g} /$ serving), which was substantially more per serving than in the other foods. Importantly, total dietary fiber was $>50 \%$ of total carbohydrates in all samples except for wild plums (22\%), raw prairie turnips (24\%), and beaked hazelnuts (43\%). Wild plums, prairie turnips, wild raspberries, and chokecherries had the highest dietary fiber contents per serving (10.6-15.0 g), with two servings meeting the dietary guidelines for daily fiber intake (Institute of Medicine, 2002). Most of the fiber was insoluble, with raw plains prickly pear having the highest soluble fiber content per serving (3.7 g; $2.5 \mathrm{~g} / 100 \mathrm{~g}$ ) and as a proportion of total fiber ( 50\%).

\subsubsection{Macro- and trace-elements}

Overall the traditional Native American plant foods were excellent sources of several macro- and trace-elements, particularly manganese (Table 5). Mn was $\geq 10 \%$ of the DRI per $100 \mathrm{~g}$ fresh weight in all foods except wild plums, wild raspberries, and stinging nettles, and those products still contained 5-9.8\% DRI per serving. On a per serving basis, cattail broad leaf shoots, beaked hazelnuts, and steamed lambsquarters were especially notable sources of $\mathrm{Mn}$, providing $81 \%, 84 \%$, and $122 \%$ of the DRI (1868-2808 $\mu \mathrm{g})$. All of the foods except wild plums, wild raspberries, and stinging nettles had $\mathrm{Mg} \geq 10 \%$ DRI per serving. For other elements some of the foods had very high levels per serving relative to the DRI. Per serving of steamed lambsquarters, calcium (628 mg), potassium (1926 mg), and magnesium ( $295 \mathrm{mg}$ ) were all $>40 \%$ of the DRI. A few of the foods (cattail broad leaf shoots, steamed lambsquarters, and prairie turnips) were good sources of iron (10\% DRI per serving). For some elements most foods were a minor source, but one or two foods had a particularly high content. For example, most foods were low in selenium but prairie turnips were a rich source with $14.7 \mu \mathrm{g} / 100 \mathrm{~g}$ fresh weight $(19.1 \mu \mathrm{g} /$ serving, 35\% DRI), and beaked hazelnuts contained 34\% of the DRI for copper per serving (305 $\mu \mathrm{g}$ ).

\subsubsection{Vitamins}

Several of the foods provide a substantial amount of vitamin B6, thiamin, vitamin $\mathrm{C}$, and vitamin $\mathrm{K}$ (Table 6). Prairie turnips (raw and boiled) and steamed lambsquarters were the richest sources of 
vitamin $\mathrm{B}_{6}$ (pyridoxine), and contained $>40 \%$ of the DRI per serving $(0.619,0.650$ and $0.418 \mathrm{mg}$, respectively). Chokecherries and broiled plains prickly pear also contained vitamin B6 at $>10 \%$ of the DRI per serving $(0.146$ and $0.198 \mathrm{mg} / 100 \mathrm{~g}, 0.149$ and $0.168 \mathrm{mg} /$ serving). Prairie turnips (raw and boiled) and beaked hazelnuts had relatively high thiamin contents $(0.126-0.550 \mathrm{mg} / 100 \mathrm{~g}, 0.140-$ $0.231 \mathrm{mg} /$ serving). Vitamin C was notably high in wild rose hips relative to the other foods and contained $227 \%$ of the DRI per $48-\mathrm{g}$ serving (205 mg). Wild plums, wild raspberries, and raw plains prickly pear were also rich in vitamin C (10.3-26.4 mg/100 g, and $\geq 10 \% \mathrm{DRI} /$ serving). Lambsquarters and stinging nettles were by far the highest in vitamin $\mathrm{K}$ and were particularly good sources, with $347 \mathrm{mg} / 100 \mathrm{~g}$ (raw) (87\% DRI/serving) and $499 \mathrm{mg} / 100 \mathrm{~g}$ (83\% DRI), respectively. Wild plums, chokecherries, cattail broad leaf shoots, and wild rose hips also were excellent sources of vitamin $\mathrm{K}$ (11.2-25.9 $\mu \mathrm{g} / 100 \mathrm{~g} ; \geq 10 \% \mathrm{DRI} /$ serving).
Only steamed lambsquarters showed high riboflavin content per serving $(0.370 \mathrm{mg} / 100 \mathrm{~g}, 51 \% \mathrm{DRI})$. Chokecherries, raw and boiled prairie turnips, wild rose hips, beaked hazelnuts all contained riboflavin $\geq 10 \%$ DRI. However, it should be noted that the inherent high RSD for this assay as indicated by the results for the control samples (see Table 6) precludes drawing a definitive interpretation of results based on from the limited number of analyses. Other vitamins were present at lower amounts in all of the foods. Moderate contents (5-10\% DRI/serving) of niacin were found in broiled plains prickly pear, raw and boiled prairie turnips, beaked hazelnuts; and pantothenic acid in chokecherries, wild plums, wild rose hips). Choline was $<4 \% \mathrm{DRI} /$ serving in all of the foods, with the highest amount of total choline in cattail broad leaf shoots $(23.7 \mathrm{mg} / 100 \mathrm{~g})$.

Only lambsquarters contained significant levels of total folate, with $96.8 \mu \mathrm{g} / 100 \mathrm{~g}$ (raw) and 7.3\% DRI per serving (Table 7). Total

Table 3

Traditional foraged Native American Northern Plains plant foods.

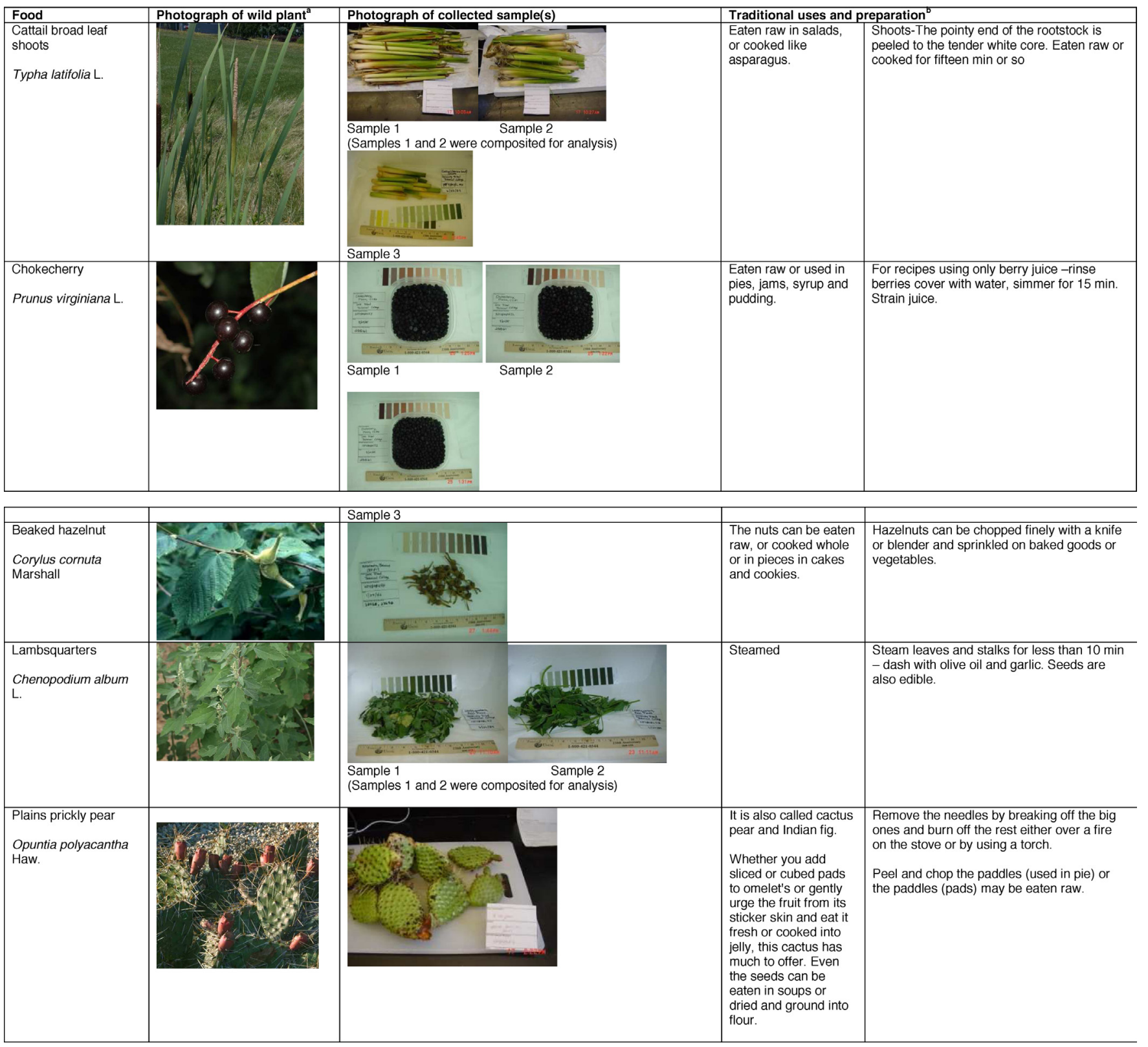


Table 3 (Continued)

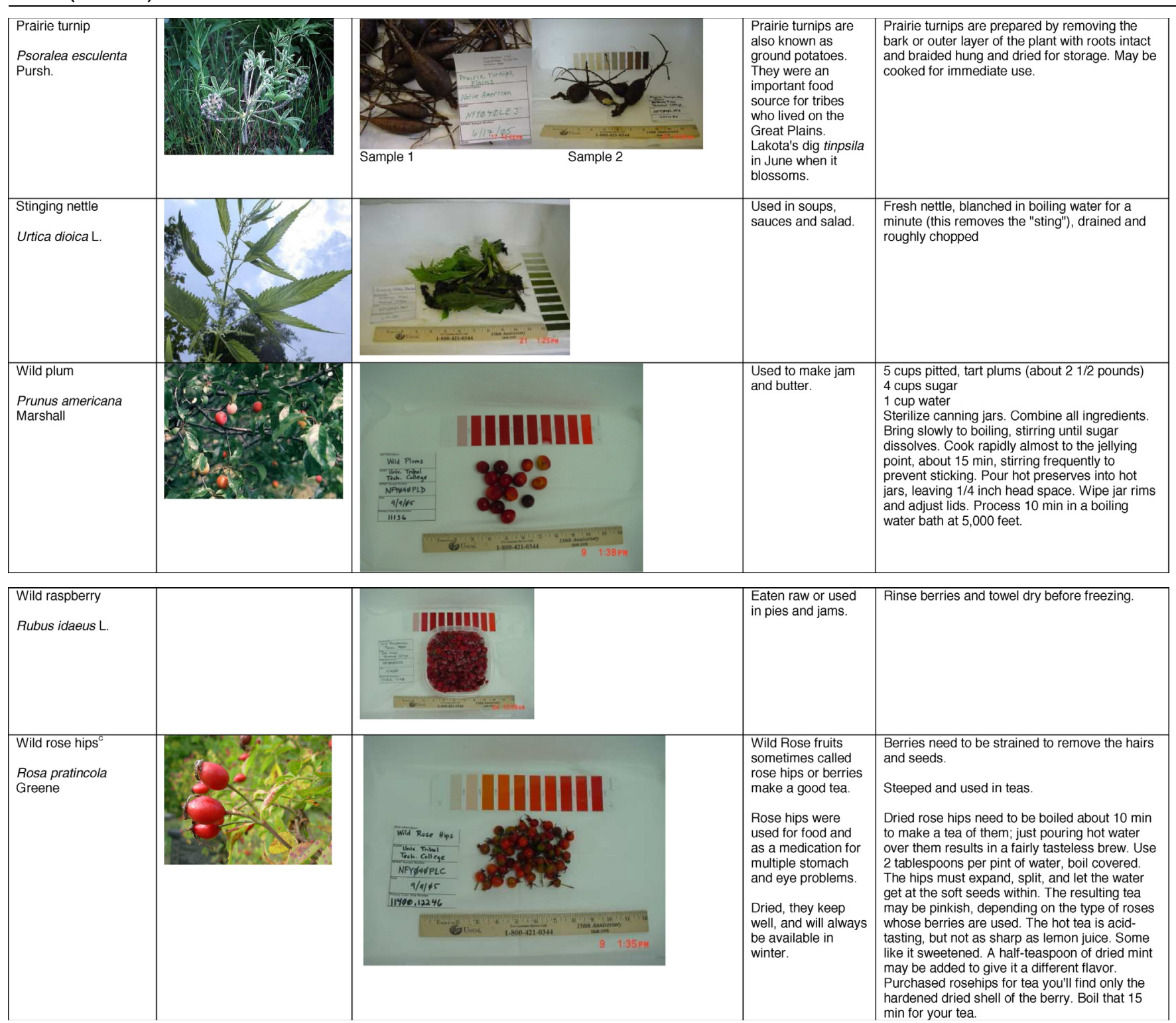

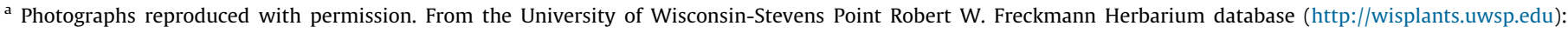

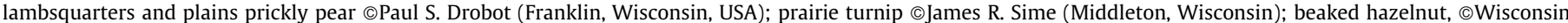

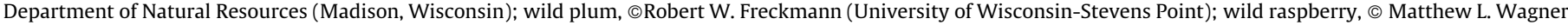

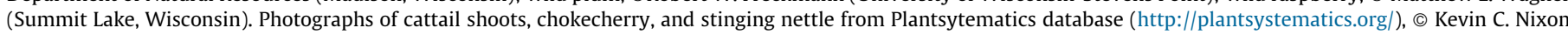
(Cornell Univeristy, Ithaca, New York, USA). Photograph of rose hips ( Rob Hull (Marvao, Portugal).

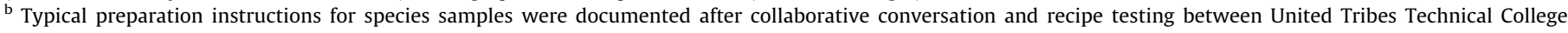
(Bismarck, North Dakota, USA) Extension staff and invited tribal elders.

${ }^{c}$ Also known as prairie rose (Rosa arkansana Porter var. suffulta (Greene) Cockerell) (USDA Natural Resources Conservation Service, 2013).

folate was $>10 \mu \mathrm{g}$ per $100 \mathrm{~g}$ fresh weight in prairie turnips, stinging nettles, and cattail broad leaf shoots, but was negligible $(<10 \mu \mathrm{g} / 100 \mathrm{~g})$ in the other foods. The major vitamer in all cases was 5 -methyltetrahydrofolate $\left(5-\mathrm{H}_{3} \mathrm{C}-\mathrm{H}_{4}\right.$ folate), except in cattail broad leaf shoots in which 10 -formyl folate (10-HCO folate) predominated. Lambsquarters also showed notable 10 -formylfolate and 5-formyltetrahydrofolate $\left(5-\mathrm{HCO}-\mathrm{H}_{4}\right.$ folate) contents.

Many of the traditional plant foods were rich in carotenoids (Table 8$)$. Total carotenoids were by far the highest in wild rose hips $(11.8 \mathrm{mg} / 100 \mathrm{~g})$. Wild plums, stinging nettles, and lambsquarters also contained substantial concentrations $(3.2-8.5 \mathrm{mg} /$ $100 \mathrm{~g}) . \beta$-Carotene and lutein + zeaxanthin were the predominant vitamers in all cases, as illustrated in Fig. 2. $\alpha$-Carotene was found only in wild plums, stinging nettles, and wild rose hips, $\alpha-$ cryptoxanthin only in wild plums and wild rose hips, $\beta$ cryptoxanthin only in wild raspberries, chokecherries, wild plums, and wild rose hips, and lycopene only in wild rose hips. The lycopene content of wild rose hips was significant $(6.8 \mathrm{mg} /$ $100 \mathrm{~g}$ ) and represented more than half of total carotenoids (Fig. 2). HPLC chromatograms are shown in Fig. 3 to illustrate the carotenoid profile of a representative sample of each food analyzed.

\subsection{Dietary contributions of traditional and comparable conventional plant foods}

In the following sections the nutrient contents of the traditional Native American plant foods relative to their contemporary 
Table 4

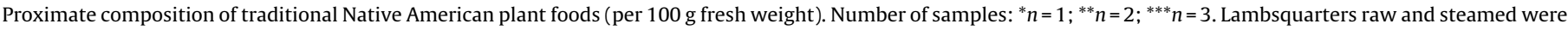
each a composite of samples from two locations (see Table 3).

\begin{tabular}{|c|c|c|c|c|c|c|c|c|c|c|c|}
\hline \multirow[t]{2}{*}{ Food } & \multirow[t]{2}{*}{ Serving Size $(\mathrm{g})$} & \multicolumn{2}{|c|}{ Energy $^{\mathrm{a}}$} & \multirow[t]{2}{*}{ Total fat } & \multirow[t]{2}{*}{ Moisture } & \multirow[t]{2}{*}{ Nitrogen } & \multirow[t]{2}{*}{ Protein } & \multirow[t]{2}{*}{ Ash } & \multicolumn{3}{|l|}{ Fiber } \\
\hline & & kcal & $\mathrm{kJ}$ & & & & & & Total $^{\mathrm{b}}$ & Insoluble & Soluble \\
\hline Cattail broad leaf shoots** & 90 & 25 & 105 & 0.1 & 92.65 & 0.2 & 1.2 & 1.03 & $4.5(87 \%)$ & 4.2 & 0.3 \\
\hline Chokecherries ${ }^{* * *}$ & 75 & 162 & 678 & 1.7 & 60.72 & 0.5 & 3.0 & 0.93 & $20.0(60 \%)$ & 18.5 & 1.5 \\
\hline Lambsquarters, raw** & 30 & 47 & 197 & 0.3 & 85.23 & 0.7 & 4.2 & 3.32 & $6.3(90 \%)$ & 4.8 & 1.5 \\
\hline Lambsquarters, steamed ${ }^{* *}$ & 180 & 48 & 201 & 0.2 & 85.02 & 0.6 & 4.1 & 3.30 & $5.2(69 \%)$ & 4.1 & 1.1 \\
\hline Plains pricklypear, raw* & 149 & 42 & 176 & 0.1 & 89.22 & 0.0 & 0.1 & 0.38 & $5.3(52 \%)$ & 2.8 & 2.5 \\
\hline Plains pricklypear, broiled* & 115 & 91 & 381 & 0.3 & 75.83 & 0.1 & 0.4 & 1.90 & $\mathrm{n} / \mathrm{a}$ & $\mathrm{n} / \mathrm{a}$ & $\mathrm{n} / \mathrm{a}$ \\
\hline Wild plums* & 132 & 157 & 657 & 0.4 & 76.68 & 0.4 & 2.6 & 0.8 & $8.0(22 \%)$ & 7.4 & 0.7 \\
\hline Prairie turnips, raw** & 130 & 130 & 544 & 0.3 & 60.70 & 0.3 & 1.6 & 0.65 & $7.2(24 \%)$ & 6.1 & 1.1 \\
\hline Prairie turnips, boiled** & 156 & 62 & 260 & 0.3 & 67.68 & 0.2 & 1.1 & 0.36 & $7.5(54 \%)$ & 6.9 & 0.6 \\
\hline Wild raspberries* & 61.5 & 162 & 678 & 0.3 & 84.48 & 0.3 & 1.6 & 0.28 & $24.1(63 \%)$ & 21.2 & 2.9 \\
\hline Wild rose hips* & 48 & 32 & 134 & 0.1 & 58.66 & 0.5 & 3.2 & 1.18 & $4.8(100 \%)$ & 4.5 & $<0.5$ \\
\hline Stinging nettles, blanched ${ }^{* *}$ & 20 & 42 & 176 & 0.1 & 87.67 & 0.4 & 2.7 & 2.03 & $6.9(92 \%)$ & & \\
\hline Beaked hazelnuts* & 25.4 & 628 & 2629 & 53.0 & 5.92 & 2.4 & 14.9 & 3.22 & $9.8(43 \%)$ & & \\
\hline Mixed Vegetable Control Composite, mean $(R S D, n)^{\mathrm{c}}$ & & & & $\begin{array}{l}0.29 \\
(52.3,4)\end{array}$ & $\begin{array}{l}90.64 \\
(0.6,5)\end{array}$ & & $\begin{array}{l}1.6 \\
(7.4,5)\end{array}$ & & $\begin{array}{l}2.4 \\
(10.3,6)\end{array}$ & $\begin{array}{l}1.8 \\
(0.1,4)\end{array}$ & $\begin{array}{l}0.6 \\
(26.1,4)\end{array}$ \\
\hline Peanut Butter Control Composite, mean (\%RSD, $n)^{\mathrm{C}}$ & & & & $\begin{array}{l}52.47 \\
(2.5,7)\end{array}$ & $\begin{array}{l}1.15 \\
(15.7,8)\end{array}$ & & & & $\begin{array}{l}5 \\
(3.3,6)\end{array}$ & & \\
\hline
\end{tabular}

n/a = not assayed.

a Calculated using the Atwater system based on assayed moisture, protein, fat content (Merrill and Watt, 1973).

b Total fiber as percent of total carbohydrates shown in parentheses.

c Relative standard deviation (RSD) for the control composite assayed with samples at the same laboratory, by the same method, over multiple days, as an estimate of analytical uncertainty in concentrations reported for samples.

Table 5

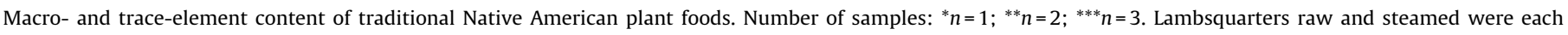
composite of samples from the same two locations. One cattail broad leaf shoots sample was a composite of material from two locations (see Table 3 ).

\begin{tabular}{|c|c|c|c|c|c|c|c|c|c|c|c|}
\hline \multirow[t]{3}{*}{ Food } & \multirow[t]{3}{*}{$\begin{array}{l}\text { Serving } \\
\text { size }(\mathrm{g})\end{array}$} & \multicolumn{10}{|c|}{ Concentration (per/100g fresh weight) ${ }^{a}$} \\
\hline & & \multicolumn{5}{|c|}{ Macroelements (mg) } & \multicolumn{5}{|c|}{ Trace elements $(\mu \mathrm{g})$} \\
\hline & & $\mathrm{Ca}$ & $\mathrm{Mg}$ & $\mathrm{K}$ & $\mathrm{Na}$ & $\mathrm{P}$ & $\mathrm{Cu}$ & $\mathrm{Fe}$ & $\mathrm{Mn}$ & $\mathrm{Zn}$ & $\mathrm{Se}$ \\
\hline Cattail broad leaf shoots** & 90 & 54 & 63 & 309 & 109 & 45 & 41 & 909 & 2075 & 245 & 0.6 \\
\hline Chokecherries*** & 75 & 60 & 27 & 379 & $<9$ & 67 & 186 & 685 & 417 & 328 & $\mathrm{n} / \mathrm{a}$ \\
\hline Lambsquarters, raw** & 30 & 366 & 163 & 1270 & $<9$ & 63 & 120 & 1160 & 1490 & 721 & 1.1 \\
\hline Lambsquarters, steamed** & 180 & 349 & 164 & 1070 & $<9$ & 56 & 100 & 1150 & 1560 & 611 & $\mathrm{n} / \mathrm{a}$ \\
\hline Plains pricklypear, raw* & 115 & 180 & 69 & 130 & $<9$ & 11 & 25 & 200 & 583 & 138 & 0.1 \\
\hline Wild plums* & 132 & 11 & 8 & 364 & $<9$ & 30 & 35 & 174 & 76 & 94 & $\mathrm{n} / \mathrm{a}$ \\
\hline Prairie turnips, raw** & 130 & 130 & 63 & 156 & $<9$ & 31 & 53 & 1270 & 266 & 371 & 14.7 \\
\hline Prairie turnips, boiled** & 156 & 103 & 49 & 108 & $<9$ & 21 & 38 & 955 & 209 & 277 & $\mathrm{n} / \mathrm{a}$ \\
\hline Wild raspberries* & 61.5 & 36 & 26 & 175 & $<9$ & 41 & 97 & 645 & 368 & 470 & $\mathrm{n} / \mathrm{a}$ \\
\hline Wild rose hips* & 48 & 169 & 69 & 429 & $<9$ & 61 & 113 & 1060 & 1020 & 245 & $\mathrm{n} / \mathrm{a}$ \\
\hline Stinging nettles, blanched** & 20 & 452 & 54 & 352 & $<9$ & 87 & 86 & 1260 & 591 & 363 & 0.3 \\
\hline Beaked hazelnuts* & 25.4 & 441 & 235 & 738 & 10 & 411 & 1200 & 3120 & 7600 & 2060 & $\mathrm{n} / \mathrm{a}$ \\
\hline $\begin{array}{l}\text { Mixed Vegetable Control } \\
\text { Composite, mean }(R S D, n)^{b}\end{array}$ & & $\begin{array}{c}38.5 \\
(4.7 \%, 7)\end{array}$ & $\begin{array}{c}19.2 \\
(4.2 \%, 7)\end{array}$ & $\begin{array}{c}201 \\
(5.2 \%, 7)\end{array}$ & $\begin{array}{c}70.2 \\
(9.8 \%, 7) \\
\end{array}$ & $\begin{array}{c}37.6 \\
(3.2 \%, 7)\end{array}$ & $\begin{array}{c}99 \\
(25.6 \%, 7) \\
\end{array}$ & $\begin{array}{c}780 \\
(6.0 \%, 7)\end{array}$ & $\begin{array}{c}180 \\
(6.5 \%, 7)\end{array}$ & $\begin{array}{c}340 \\
(4.5 \%, 7)\end{array}$ & $\mathrm{n} / \mathrm{a}$ \\
\hline $\begin{array}{l}\text { Starchy Vegetable Control } \\
\text { Composite, mean }(R S D, n)^{\mathrm{b}}\end{array}$ & & $\begin{array}{c}21.5 \\
(1.2 \%, 3) \\
\end{array}$ & $\begin{array}{c}24.7 \\
(0.5 \%, 5) \\
\end{array}$ & $\begin{array}{c}323 \\
(1.9 \%, 5) \\
\end{array}$ & $\begin{array}{c}117 \\
(4.9 \%, 5) \\
\end{array}$ & $\begin{array}{c}70.7 \\
(1.8 \%, 5) \\
\end{array}$ & $\begin{array}{c}120 \\
(3.0 \%, 5) \\
\end{array}$ & $\begin{array}{c}880 \\
(0.8 \%, 5) \\
\end{array}$ & $\begin{array}{c}270 \\
(0.9 \%, 4) \\
\end{array}$ & $\begin{array}{c}420 \\
(1.2 \%, 4) \\
\end{array}$ & $\begin{array}{c}2.4 \\
(6.5 \%, 3) \\
\end{array}$ \\
\hline \multirow[t]{2}{*}{$\mathrm{DRI}^{\mathrm{c}}$} & Male & $\begin{array}{c}1000- \\
1200 \\
\end{array}$ & $400-420$ & 4700 & $\begin{array}{c}1200- \\
1500 \\
\end{array}$ & 700 & 900 & 8000 & 2300 & 11,000 & 55 \\
\hline & Female & $\begin{array}{c}1000- \\
1200\end{array}$ & $310-320$ & 4700 & $\begin{array}{c}1200- \\
1500\end{array}$ & 700 & 900 & 18,000 & 1800 & 8000 & 55 \\
\hline
\end{tabular}

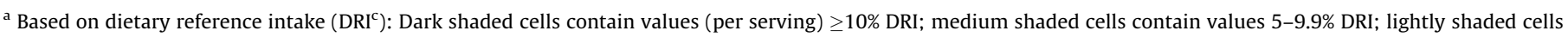
indicate values 2-4.9\% DRI; values in unshaded cells are $<2 \%$ DRI; values in cells with bolded outline are $>40 \%$ DRI.

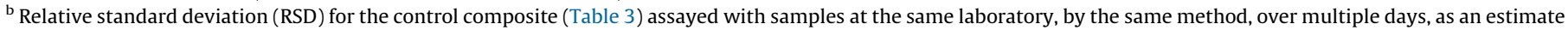
of analytical uncertainty in concentrations reported for samples.

c Institute of Medicine (1997, 2000, 2001, 2004, 2011) 
Table 6

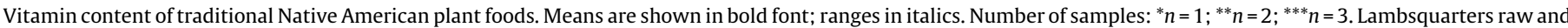

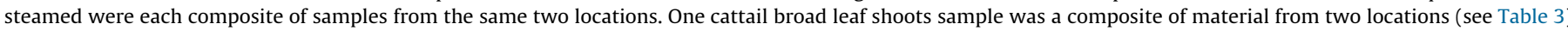

\begin{tabular}{|c|c|c|c|c|c|c|c|c|c|}
\hline \multirow[t]{2}{*}{ Food } & \multirow[t]{2}{*}{ Serving size (g) } & \multicolumn{8}{|c|}{ Concentration per $/ 100 \mathrm{~g}$ fresh weight ${ }^{\mathrm{a}}$} \\
\hline & & Niacin (mg) & $\begin{array}{c}\text { Pantothenic } \\
\text { acid (mg) }\end{array}$ & $\begin{array}{c}\text { Vitamin B6 } \\
(\mathrm{mg})\end{array}$ & $\begin{array}{c}\text { Riboflavin } \\
\text { (mg) }\end{array}$ & $\begin{array}{l}\text { Thiamin } \\
\text { (mg) }\end{array}$ & $\begin{array}{l}\text { Vitamin } \\
\text { C (mg) }\end{array}$ & $\begin{array}{c}\text { Vitamin K } \\
(\mu \mathrm{g})\end{array}$ & $\begin{array}{l}\text { Total } \\
\text { choline } \\
\text { (mg) }\end{array}$ \\
\hline \multirow[t]{2}{*}{ Cattail broad leaf shoots** } & 90 & 0.441 & 0.235 & 0.123 & $<0.100$ & 0.023 & 1.0 & 22.8 & 23.7 \\
\hline & & $0.327-0.554$ & $0.154-0.315$ & $0.094-0.141$ & $0.020-0.078$ & $0.008-0.037$ & $1.0-1.0$ & & \\
\hline \multirow[t]{2}{*}{ Chokecherries*** } & 75 & 0.628 & 0.398 & 0.198 & 0.173 & 0.034 & 4.0 & 21.1 & n/a \\
\hline & & $0.563-0.732$ & $0.338-0.463$ & $0.155-0.231$ & $0.114-0.242$ & $0.031-0.037$ & $1.0-9.4$ & & \\
\hline \multirow[t]{2}{*}{ Lambsquarters, raw** } & 30 & 0.790 & 0.300 & 0.184 & 0.394 & 0.029 & 1.0 & 347 & 20.0 \\
\hline & & & $0.270-0.330$ & & $0.300-0.487$ & & & & \\
\hline \multirow[t]{2}{*}{ Lambsquarters, steamed** } & 180 & 0.623 & $\mathrm{n} / \mathrm{a}$ & 0.232 & 0.370 & 0.047 & 4.9 & $n / a$ & $\mathrm{n} / \mathrm{a}$ \\
\hline & & & & & $0.270-0.470$ & & & & \\
\hline Plains pricklypear, raw* & 149 & 0.293 & 0.060 & 0.079 & $<0.100$ & 0.008 & 11.3 & 2.9 & 4.3 \\
\hline Plains pricklypear, broiled* & 115 & 1.000 & 0.150 & 0.146 & $<0.100$ & 0.018 & 6.2 & $n / a$ & $n / a$ \\
\hline Wild plums* & 132 & 0.367 & 0.301 & 0.093 & $<0.100$ & 0.005 & 10.3 & 11.2 & 5.2 \\
\hline \multirow[t]{2}{*}{ Prairie turnips, raw** } & 130 & 1.071 & 0.155 & 0.476 & $<0.100$ & 0.178 & 5.6 & 0.0 & 4.8 \\
\hline & & $0.972-1.17$ & $0.150-0.160$ & $0.456-0.483$ & $0.087-0.095$ & $0.136-0.220$ & $4.2-6.9$ & & \\
\hline \multirow[t]{2}{*}{ Prairie turnips, boiled** } & 156 & 0.708 & 0.090 & 0.417 & $<0.100$ & 0.126 & 2.1 & $n / a$ & $n / a$ \\
\hline & & $0.549-0.867$ & $0.070-0.110$ & $0.342-0.417$ & $0.039-0.044$ & $0.126-0.126$ & $1.0-3.2$ & & \\
\hline Wild raspberries* & 61.5 & 1.030 & 0.300 & 0.104 & $<0.100$ & 0.018 & 26.4 & 6.6 & 9.5 \\
\hline
\end{tabular}

\begin{tabular}{|c|c|c|c|c|c|c|c|c|c|}
\hline \multirow[t]{2}{*}{ Food } & \multirow[t]{2}{*}{ Serving size $(\mathrm{g})$} & \multicolumn{8}{|c|}{ Concentration per $/ 100 \mathrm{~g}$ fresh weight ${ }^{\mathrm{a}}$} \\
\hline & & Niacin (mg) & $\begin{array}{l}\text { Pantothenic } \\
\text { acid (mg) }\end{array}$ & $\begin{array}{c}\text { Vitamin B6 } \\
\text { (mg) }\end{array}$ & $\begin{array}{l}\text { Riboflavin } \\
\text { (mg) }\end{array}$ & $\begin{array}{l}\text { Thiamin } \\
\text { (mg) }\end{array}$ & $\begin{array}{l}\text { Vitamin } \\
C(\mathrm{mg})\end{array}$ & $\begin{array}{c}\text { Vitamin } \mathrm{K} \\
(\mu \mathrm{g})\end{array}$ & $\begin{array}{l}\text { Total } \\
\text { choline } \\
\text { (mg) }\end{array}$ \\
\hline Wild rose hips* & 48 & 1.300 & 0.800 & 0.076 & 0.166 & 0.016 & 426 & 25.9 & 12.0 \\
\hline \multirow[t]{2}{*}{ Stinging nettles, blanched** } & 20 & 0.371 & 0.155 & 0.104 & 0.160 & 0.008 & 1.0 & 499 & 17.4 \\
\hline & & $0.371-0.406$ & $0.140-0.170$ & $0.100-0.107$ & $0.152-0.168$ & $0.008-0.008$ & $1.0-1.0$ & & \\
\hline Beaked hazelnuts* & 25.4 & 3.190 & 1.200 & 0.160 & 0.480 & 0.550 & $n / a$ & $n / a$ & $n / a$ \\
\hline $\begin{array}{l}\text { Mixed Vegetable Control } \\
\text { Composite, mean (RSD, } n)^{b}\end{array}$ & & $\begin{array}{c}0.531 \\
(5.9 \%, 9)\end{array}$ & $\begin{array}{c}0.188 \\
(3.8 \%, 3)\end{array}$ & $\begin{array}{c}0.070 \\
(14.5 \%, 7)\end{array}$ & $\begin{array}{c}0.067 \\
(51.2 \%, 10)\end{array}$ & $\begin{array}{c}0.036 \\
(12.2 \%, 7) \\
\end{array}$ & $\mathrm{n} / \mathrm{a}$ & $\begin{array}{c}48.5 \\
(10.9 \%, 7) \\
\end{array}$ & $\begin{array}{c}2.08 \\
(5.2 \%, 2) \\
\end{array}$ \\
\hline $\begin{array}{l}\text { Starchy Vegetable Control } \\
\text { Composite, mean (RSD, n) }\end{array}$ & & $\begin{array}{c}0.765 \\
(4.3 \%, 5)\end{array}$ & $\begin{array}{c}0.330 \\
(0.6 \%, 2)\end{array}$ & $\begin{array}{c}0.134 \\
(11.2 \%, 4) \\
\end{array}$ & $\begin{array}{c}0.051 \\
(67.5 \%, 9) \\
\end{array}$ & $\begin{array}{c}0.045 \\
(15.4 \%, 4) \\
\end{array}$ & $\mathrm{n} / \mathrm{a}$ & $\begin{array}{c}0.96 \\
(12.9 \%, 4) \\
\end{array}$ & $\mathrm{n} / \mathrm{a}$ \\
\hline $\begin{array}{l}\text { BCR CRM } 431 \text { Lyophilized } \\
\text { Brussels Sprouts, mean (RSD, n) })^{\mathrm{b}, \mathrm{c}}\end{array}$ & & & & & & & $\begin{array}{c}464 \\
3.1(4) \\
\end{array}$ & & \\
\hline \multirow[t]{2}{*}{$D_{R} I^{c}$} & Male & 16 & 5 & $1.3-1.7$ & 1.3 & 1.2 & 90 & 120 & 550 \\
\hline & Female & 14 & 5 & $1.3-1.5$ & 1.1 & 1.1 & 75 & 90 & 425 \\
\hline
\end{tabular}

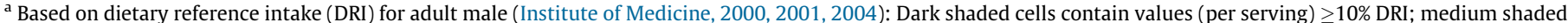
cells contain values $5-9.9 \%$ DRI; light shaded cells contain values $2-4.9 \%$ DRI; values in unshaded cells $<2 \%$ DRI; values in cells with bolded outline are $>40 \%$ DRI.

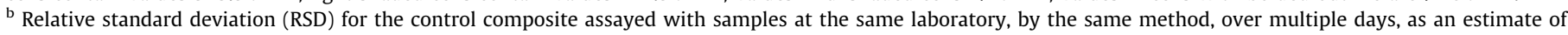
analytical uncertainty in concentrations reported for samples without replicate analyses.

${ }^{\mathrm{c}}$ Institute of Reference Materials and Methods (Geel, Belgium). Vitamin C (certified), 459-507 mg/100 g.

counterparts (Table 2) are discussed. Emphasis is placed on cases in which the traditional Native American foods provided at least twice the nutrient content per serving as the contemporary food. Table 9 summarizes the profile of each food in terms of nutrient contributions to DRIs. This analysis is important because these foods were a significant segment of the historical diets of the Plains Indians. The foods are still available in the wild and could be nutritionally significant in contemporary tribal diets if they replace the less healthy, mainstream foods pervasive in the US diet as a whole. The purpose is to show, compared to similar mainstream 
Table 7

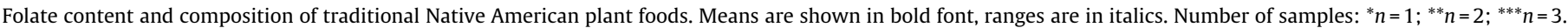

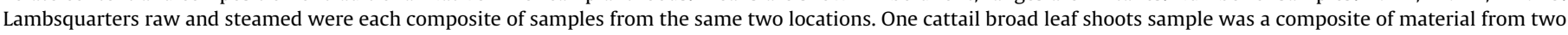
locations (see Table 3)

\begin{tabular}{|c|c|c|c|c|c|c|}
\hline \multirow[b]{3}{*}{ Food } & \multicolumn{6}{|c|}{$\mu \mathrm{g} / 100 \mathrm{~g}$ fresh weight } \\
\hline & \multirow[b]{2}{*}{$\begin{array}{l}\text { Serving } \\
\text { size }(\mathrm{g})\end{array}$} & \multirow[b]{2}{*}{$\begin{array}{l}5-\mathrm{CH}_{3}-\mathrm{H}_{4} \\
\text { Folate } \\
\end{array}$} & \multirow[b]{2}{*}{$\begin{array}{l}10-\mathrm{HCO} \\
\text { Folate }\end{array}$} & \multirow[b]{2}{*}{$\begin{array}{l}5-\mathrm{HCO}-\mathrm{H}_{4} \\
\text { Folate } \\
\end{array}$} & \multicolumn{2}{|c|}{ Sum of Folates } \\
\hline & & & & & $\begin{array}{l}\text { Folic acid } \\
\text { equivalents } \\
(\mu \mathrm{g} / 100 \mathrm{~g})^{\mathrm{a}} \\
\end{array}$ & $\begin{array}{l}\% \mathrm{DRI}^{\mathrm{b}} \\
\text { per } \\
\text { serving } \\
\end{array}$ \\
\hline \multirow[t]{2}{*}{ Cattail broad leaf shoots** } & 90 & 2.24 & 6.00 & 3.25 & 10.8 & 2.4 \\
\hline & & $1.54-2.93$ & $5.69-6.31$ & $1.73-4.78$ & $8.45-13.2$ & \\
\hline \multirow[t]{2}{*}{ Stinging nettles, blanched** } & 20 & 17.3 & 5.99 & 1.83 & 24.0 & 1.2 \\
\hline & & $13.7-21.0$ & $4.18-7.81$ & $0.900-2.76$ & $17.9-30.1$ & \\
\hline \multirow[t]{2}{*}{ Prairie turnips, raw** } & 130 & 10.2 & 0.55 & 1.28 & 11.5 & 3.8 \\
\hline & & $(4.0 \%, 3)$ & & & & \\
\hline \multirow[t]{2}{*}{ Lambsquarters, raw** } & 30 & 47.6 & 42.9 & 12.2 & 97.5 & 7.3 \\
\hline & & $(28.5 \%, 6)$ & $(13.0 \%, 2)$ & $(13.8 \%, 2)$ & & \\
\hline Wild raspberries* & 61.5 & $<8.0$ & 0.18 & 1.47 & 4.78 & 0.7 \\
\hline Chokecherries $* * *$ & 75 & $<8.0$ & 0.27 & 2.28 & 3.92 & 0.7 \\
\hline Wild rose hips* & 48 & $<8.0$ & 0.35 & 0.68 & 7.18 & 0.9 \\
\hline Wild plums* & 132 & 0.86 & 0.34 & 0.40 & 1.52 & 0.5 \\
\hline $\begin{array}{l}\text { BCR CRM } 485 \text { Freeze-Dried Mixed } \\
\text { Vegetables }^{\text {c }}\end{array}$ & & $239^{d}(43,6.3 \%)$ & $<1.0(12, \mathrm{n} / \mathrm{a})$ & $3.63(11,13.5 \%)$ & $234^{e}(8,7.1 \%)^{f}$ & \\
\hline
\end{tabular}

a Molar equivalent folic acid.

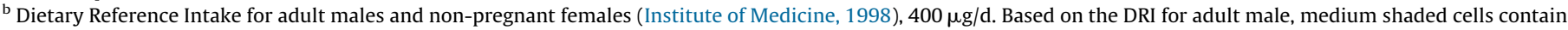
values (per serving) $\geq 5-9.9 \%$ DRI; lightly shaded cells contain values $2-4.9 \%$ RI; values in unshaded cells are $<2 \%$ DRI.

'Institute of Reference Materials and Methods (Geel, Belgium); values on dry weight basis.

${ }^{\mathrm{d}}$ Indicative range, $172-256 \mu \mathrm{g} / 100 \mathrm{~g}$ dry weight (Finglas et al., 1998).

${ }^{\mathrm{e} C e r t i f i e d ~ r a n g e}$ for total folate by microbiological assay, $287-343 \mu \mathrm{g} / 100 \mathrm{~g}$ dry weight (Finglas et al., 1998).

Table 8

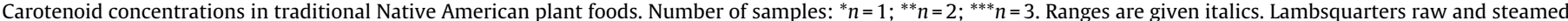
were each composite of samples from the same two locations. One cattail broad leaf shoots sample was a composite of material from two locations (see Table 3 ).

\begin{tabular}{|c|c|c|c|c|c|c|c|}
\hline \multirow[t]{2}{*}{ Food } & \multicolumn{7}{|c|}{$\mathrm{mg} / 100 \mathrm{~g}$ fresh weight } \\
\hline & $\alpha$-Carotene & $\beta$-Carotene & $\alpha$-Cryptoxanthin & $\beta$-Cryptoxanthin & Lutein + zeaxanthin & Lycopene & $\begin{array}{l}\text { Other } \\
\text { carotenoids }^{\mathrm{a}}\end{array}$ \\
\hline Cattail broad leaf shoots** & nd & 0.006 & nd & nd & 0.076 & nd & 0.046 \\
\hline Wild raspberries* & $<0.01$ & 0.013 & nd & 0.031 & 0.130 & nd & nd \\
\hline Chokecherries*** & $\begin{array}{l}<0.01 \\
(<0.01-<0.01)\end{array}$ & $\begin{array}{l}0.090 \\
(0.055-0.117)\end{array}$ & nd & $\begin{array}{l}0.019 \\
(0.017-0.024)\end{array}$ & $\begin{array}{l}0.347 \\
(0.036-0.382)\end{array}$ & nd & nd \\
\hline Wild plums* & 0.140 & 1.93 & 0.030 & 0.187 & 0.920 & nd & nd \\
\hline Lambsquarters, raw** & nd & 1.17 & nd & nd & 3.62 & nd & nd \\
\hline Lambsquarters, steamed ${ }^{* *}$ & nd & 2.33 & nd & nd & 6.16 & nd & nd \\
\hline Stinging nettles, blanched ${ }^{* *}$ & 0.114 & 1.15 & nd & nd & 4.18 & nd & nd \\
\hline Wild rose hips* & 0.031 & 2.35 & 0.084 & 0.483 & 2.00 & 6.80 & nd \\
\hline NIST SRM ${ }^{\mathbb{R}} 2383$ Babyfood $^{\mathrm{b}}(n=4)$ & $0.090(5.8 \%)$ & $0.309(2.7 \%)$ & $0.150(2.3 \%)$ & $0.148(23.6 \%)$ & $0.662(23.1 \%)$ & $0.084(8.1 \%)$ & \\
\hline [Certified range] & {$[0.067-0.099]$} & {$[0.249-0.375]$} & No value & [0.107-0.169] & {$[0.155-0.249]$} & {$\left[0.550-0.850^{\mathrm{C}}\right]$} & \\
\hline $\begin{array}{l}\text { NIST SRM } \\
\text { Spinach }^{\mathrm{B}} 2385 \text { Slurried } \\
(n=4)\end{array}$ & nd & $1.17(24.8 \%)$ & No value & nd & $3.15(6.5 \%)$ & nd & No value \\
\hline [Certified range] & & {$[1.63-2.21]$} & & & & & \\
\hline $\begin{array}{l}\text { BCR CRM } 485 \text { Lyophilized Mixed } \\
\text { Vegetables }^{\mathrm{d}}(n=3)\end{array}$ & $0.854(6.7 \%)$ & $2.07(8.7 \%)$ & No value & $0.061(54.8)$ & $1.76(27.2 \%)^{\mathrm{e}}$ & $1.20(2.3 \%)$ & No value \\
\hline [Certified range] & [910-1050] & {$[2.44-2.68]$} & & & {$[2.10-2.36]$} & & \\
\hline
\end{tabular}

$n d=$ not detected $(<0.005 \mathrm{mg} / 100 \mathrm{~g})$.

a Not identified.

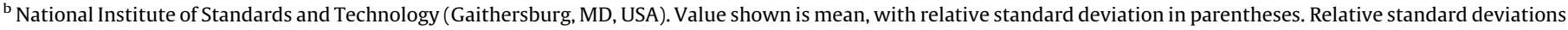

for the SRM ${ }^{\mathbb{R}}$ provide estimates of analytical uncertainty for the respective value for single analyses of food samples.

c Non-certified (reference) range.

${ }^{\mathrm{d}}$ Institute of Reference Materials and Methods (Geel, Belgium). Concentrations are on a dry weight basis; relative standard deviation in parentheses.

e Lutein: 1.08 (7.3\%), $n=2$; certified range, $1.17-1.33$ 


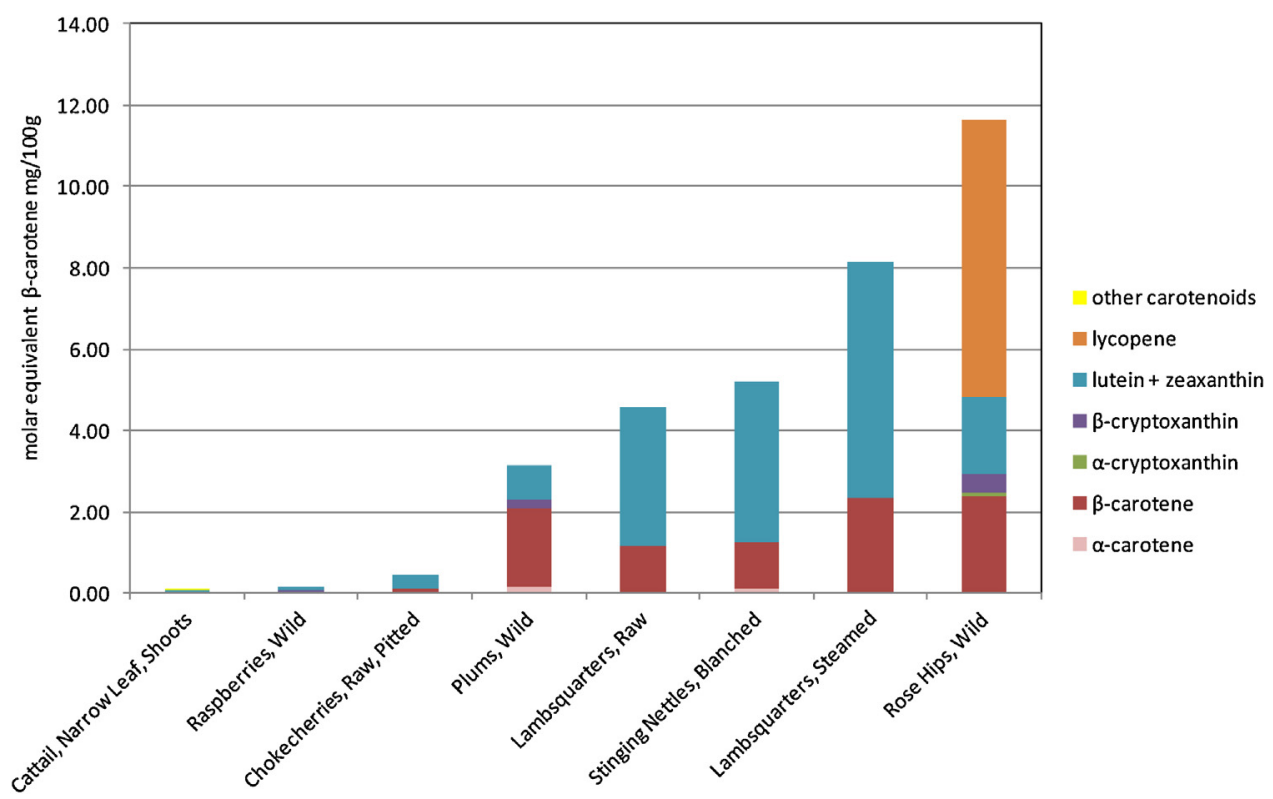

Fig. 2. Carotenoid composition of traditional Native American plant foods, as molar equivalent $\beta$-carotene mg/100 g.

plant foods, that readily available indigenous wild foods are comparable in nutritional quality and, in some cases, are higher in specific healthful components.

\subsubsection{Proximate composition}

Aside from beaked hazelnuts, none of the traditional foods or their contemporary counterparts were notable sources of fat or protein, as expected for plant foods. Beaked hazelnuts ( $C$. cornuta Marsh.) did not differ notably in fat or protein content compared to hazelnuts (filberts) (Corylus spp.) (13.6 and $15.4 \mathrm{~g}$ fat/serving, respectively, and $3.8 \mathrm{~g}$ protein/serving for both foods). On the other hand, many of the foods were rich in dietary fiber. All of the traditional foods except wild rose hips, stinging nettles, and beaked hazelnuts contained more than twice as much dietary fiber than the corresponding contemporary food (Fig. 4). In the case of chokecherries (versus gooseberries), raw plains prickly pear (versus apple), wild plums (versus plums), and prairie turnips (versus turnips), the contemporary food contained $<3 \mathrm{~g}$ total fiber per serving $[<10 \%$ of the $25-30 \mathrm{~g} /$ day DRI (IOM, 2002)], whereas the traditional counterpart provided 7.9-15 g (26-50\% of the DRI). Given the many health benefits attributed to dietary fiber (Topping, 2013), supplementing the diet with even one serving per day of these traditional foods could be recommended to significantly increase fiber intake.

Table 9

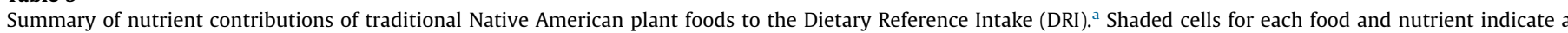
nutrient content $>10 \%$ of the DRI per serving.

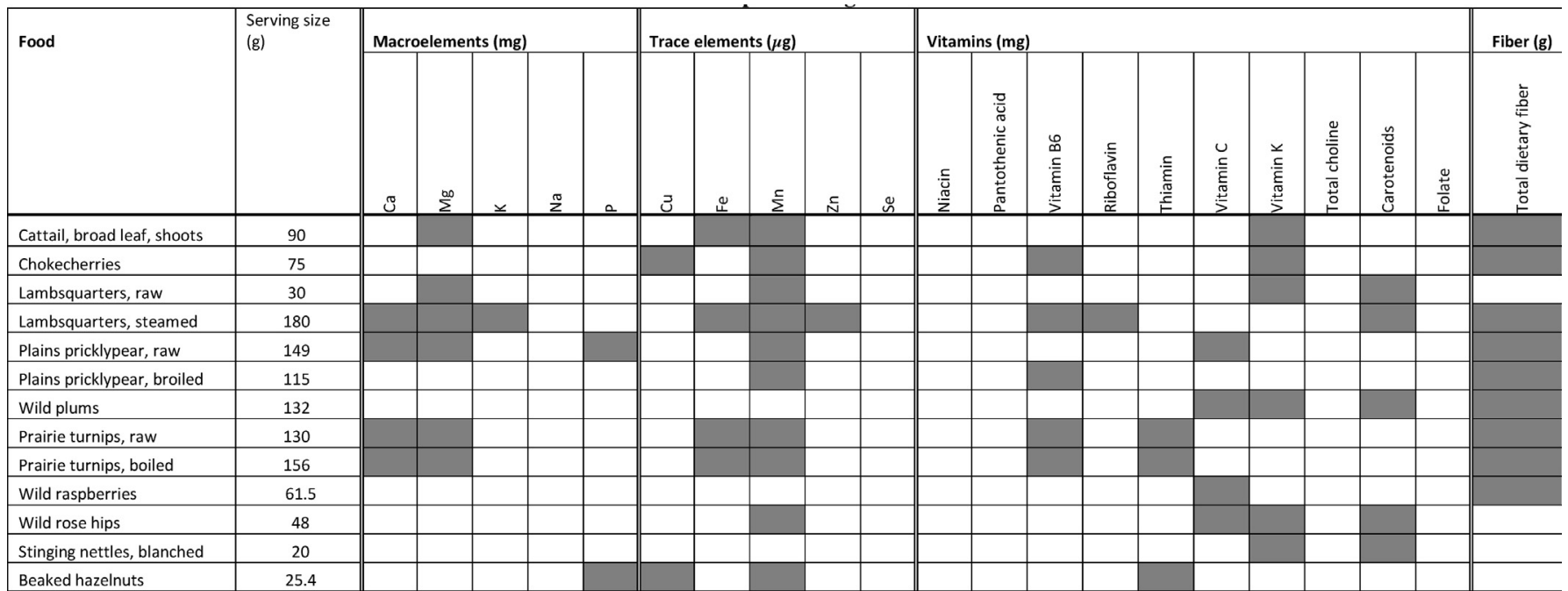

a Based on DRI for an adult male, using lower limit in cases where a range is given (Institute of Medicine, 1997, 1998, 2000, 2001, 2002, 2004, 2011). 
Cattails narrow leaf shoots

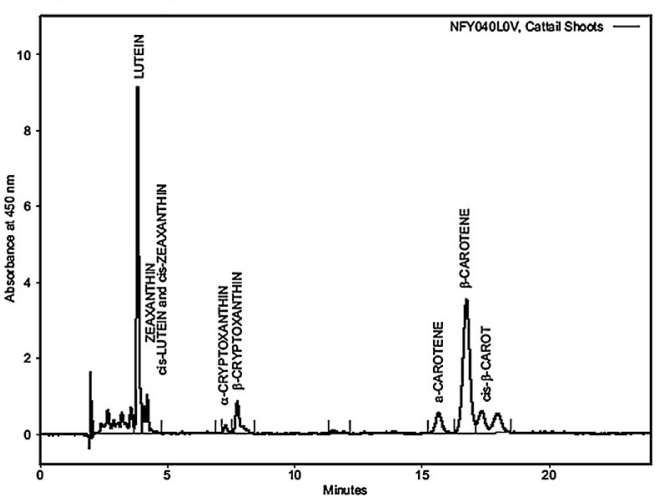

Wild Raspberries

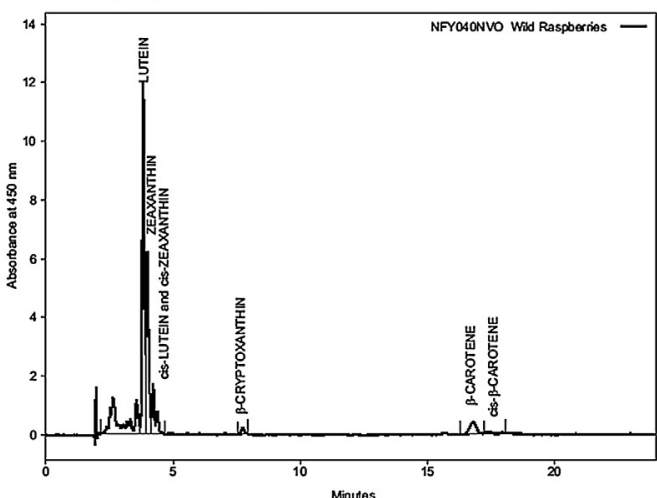

Lambsquarters, steamed

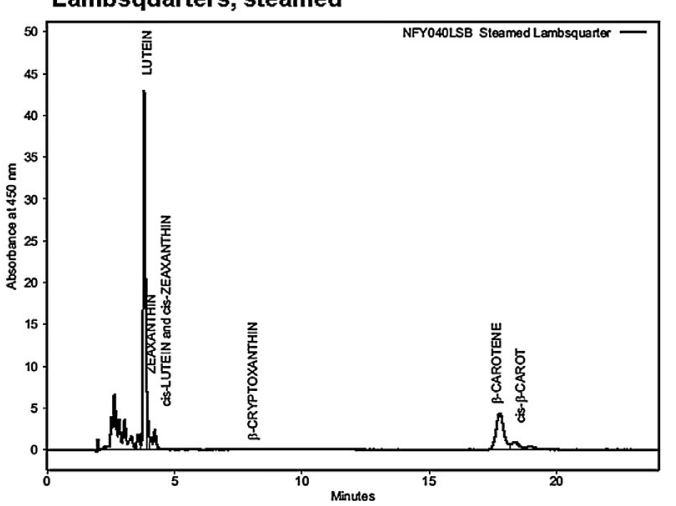

Wild plums

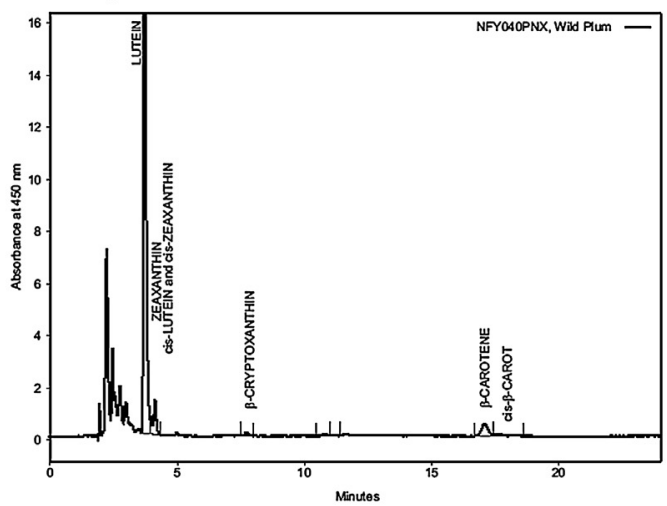

Chokecherries

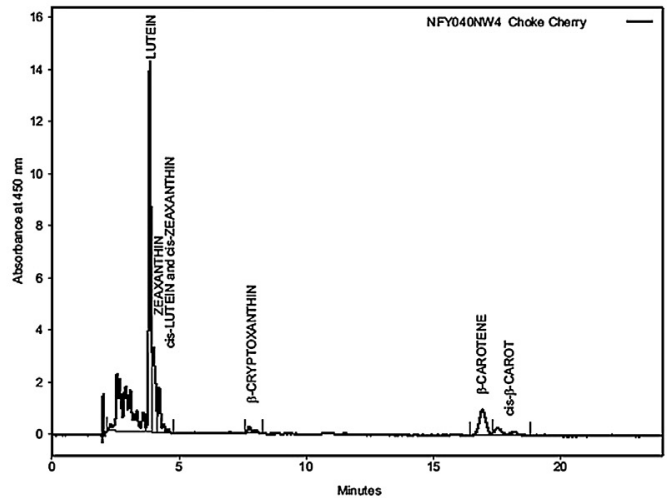

Stinging Nettles

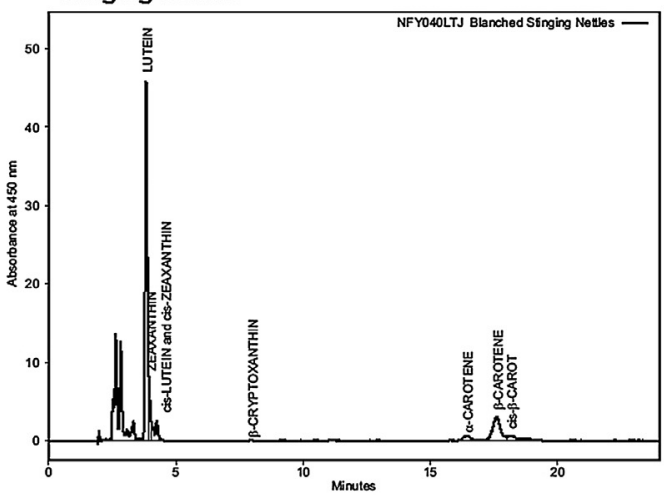

Wild rose hips

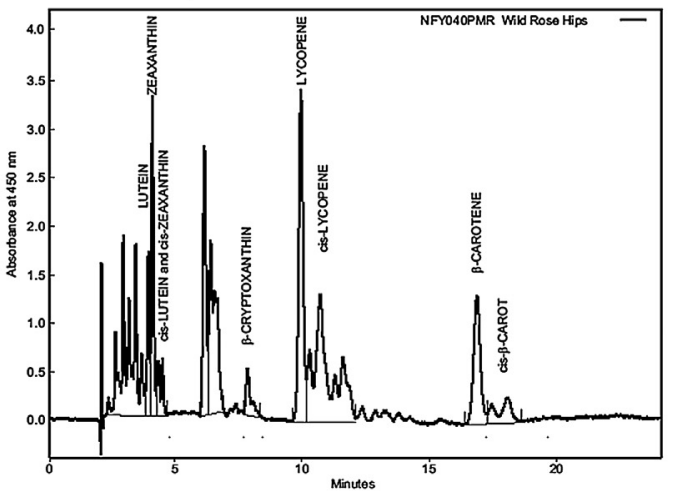

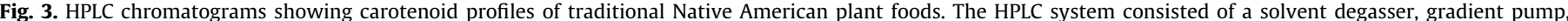

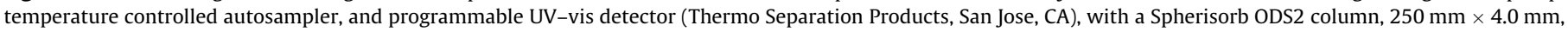

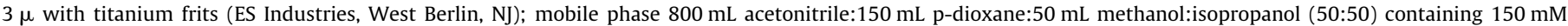
ammonium acetate and $1 \mathrm{~mL}$ triethylamine; flow rate $1.0 \mathrm{~mL} / \mathrm{min}$; detection at $450 \mathrm{~nm}$. 


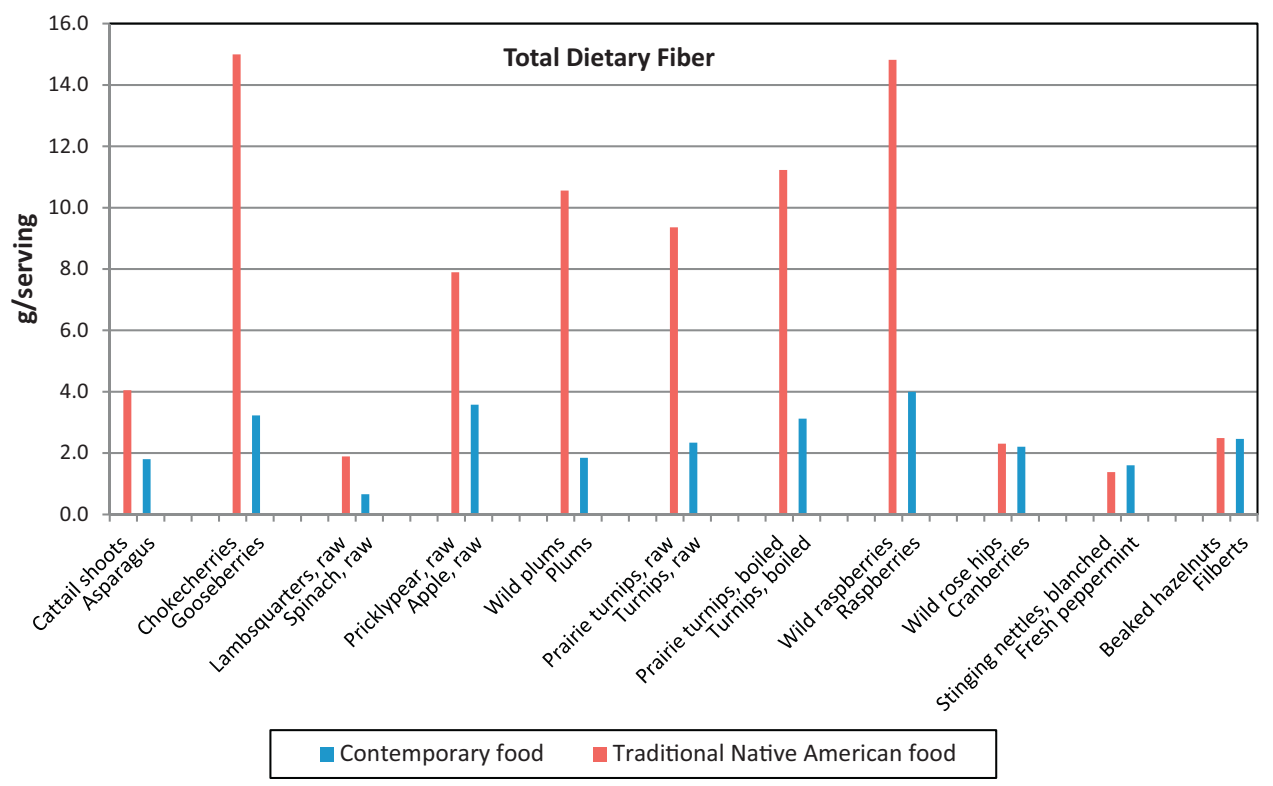

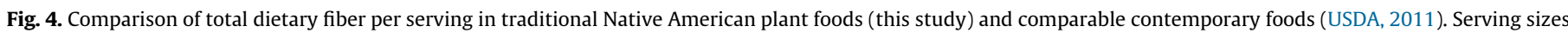
are given in Table 2 .

\subsubsection{Macro- and trace-elements}

In several cases there were differences between the macroand trace-element contents of the traditional foods and the contemporary counterpart (Fig. 5). The calcium contents of raw plains prickly pear and prairie turnips were substantially greater than in the corresponding contemporary foods (apples and turnips, respectively; 169 and 268 versus 39 and $7 \mathrm{mg} /$ serving). Boiled prairie turnips, beaked hazelnuts, broiled plains prickly pears, raw and steamed lambsquarters, cattail broad leaf shoots, chokecherries, wild plums and wild raspberries, and blanched stinging nettles had more calcium per serving than their counterparts. Similarly, raw and boiled prairie turnips, raw plains prickly pears, raw and steamed lambsquarters, cattail broad leaf shoots, and chokecherries each had substantially more magnesium than their paired contemporary plant food. Iron value contents were improved only in prairie turnips, raw and boiled, compared to regular turnips ( 81 and 1 versus 14 and $0.14 \mathrm{mg} /$ serving), although cooking reduced iron content. Lambsquarters, chokecherries, cattail broad leaf shoots, and wild plums had considerably more potassium than their contemporary counterparts. Native American cooking methods and differences in cultivar between the harvested wild plant and the domesticated version or similar plant might account for some of these differences, but assessing these variables was not part of this study and the multiple sampling locations for each food would include variation in traditional preparation methods.

\subsubsection{Vitamins}

There were some notable differences in vitamin contents between the traditional and corresponding contemporary foods (Fig. 6). Prairie turnips (raw or boiled) contained twice as much niacin as regular turnips. Beaked hazelnuts also contained more niacin than filberts ( 0.81 versus $0.46 \mathrm{mg} /$ serving). Pyridoxine and thiamin levels were substantially higher in raw and boiled prairie turnips compared to regular turnips, and in raw plains prickly pear compared to apple ( 0.12 versus $0.06 \mathrm{mg} /$ serving). Although riboflavin was higher in raw prairie turnips compared to regular turnips ( 0.26 versus $0.04 \mathrm{mg} /$ serving), boiling reduced this difference. For some foods, the level of vitamin $C$ in the traditional food was significantly higher than in its contemporary counterpart. The most remarkable was wild rose hips (204 mg/serving) compared to cranberries (6.4 mg/serving), in which the contemporary food provided $<10 \%$ of the \%DRI of vitamin C per serving, while the traditional food provided $>200 \%$ of the DRI. Vitamin C levels were also higher in raw and broiled plains prickly pear compared to apple (17 and $7 \mathrm{mg} /$ serving, respectively), although there was a marked reduction in vitamin $C$ in both of the corresponding cooked foods ( 7 and $0.3 \mathrm{mg} /$ serving, respectively). On the other hand, vitamin $C$ was higher in the contemporary food in some of the pairs. Gooseberries had $21 \mathrm{mg}$ vitamin C per serving compared to only $3.0 \mathrm{mg} /$ serving in chokecherries. Raw prairie turnips had $7.2 \mathrm{mg}$ vitamin $\mathrm{C}$ per serving compared to $27 \mathrm{mg} /$ serving in raw turnips, and the difference was similar in the corresponding boiled vegetables ( 3.3 versus $18.3 \mathrm{mg} /$ serving, respectively). In the remaining foods there was no notable difference in the vitamin $C$ content of the traditional and corresponding contemporary food or the contribution to the DRI.

Epidemiological research strongly supports increased consumption of folate- and carotenoid-rich plant foods to reduce the risk of several chronic diseases (Li et al., 2003; Moat et al., 2004; Rao and Rao, 2007). The folate DRI is $400 \mu \mathrm{g}$ (IOM, 1998), with evidence suggesting roles for specific folate vitamers (Gilbody et al., 2007; Robien and Ulrich, 2003). The folate content of the traditional and contemporary foods was difficult to compare due to differences in methodology. Measurement of naturally occurring folate by standard microbiological methodology (e.g. AOAC, 2011, Official Methods 960.46 and 992.05) shows higher variability and uncertainty than measurement of folic acid in fortified foods (Koontz et al., 2005). Folate values for the contemporary foods, taken from the USDA National Nutrient Database for Standard Reference (SR) (USDA, 2011), were determined by the microbiological assay. In this study we used the same tri-enzyme extraction that precedes quantitation of folic acid in the microbiological assay, but instead used LC-MS to measure the concentrations of the major individual folate vitamers (5-methyltetrahydrofolate, 10-formyl folic acid, and 5-formyltetrahydrofolate) and estimated "total folate" as the sum of their molar equivalent folic acid concentrations. 

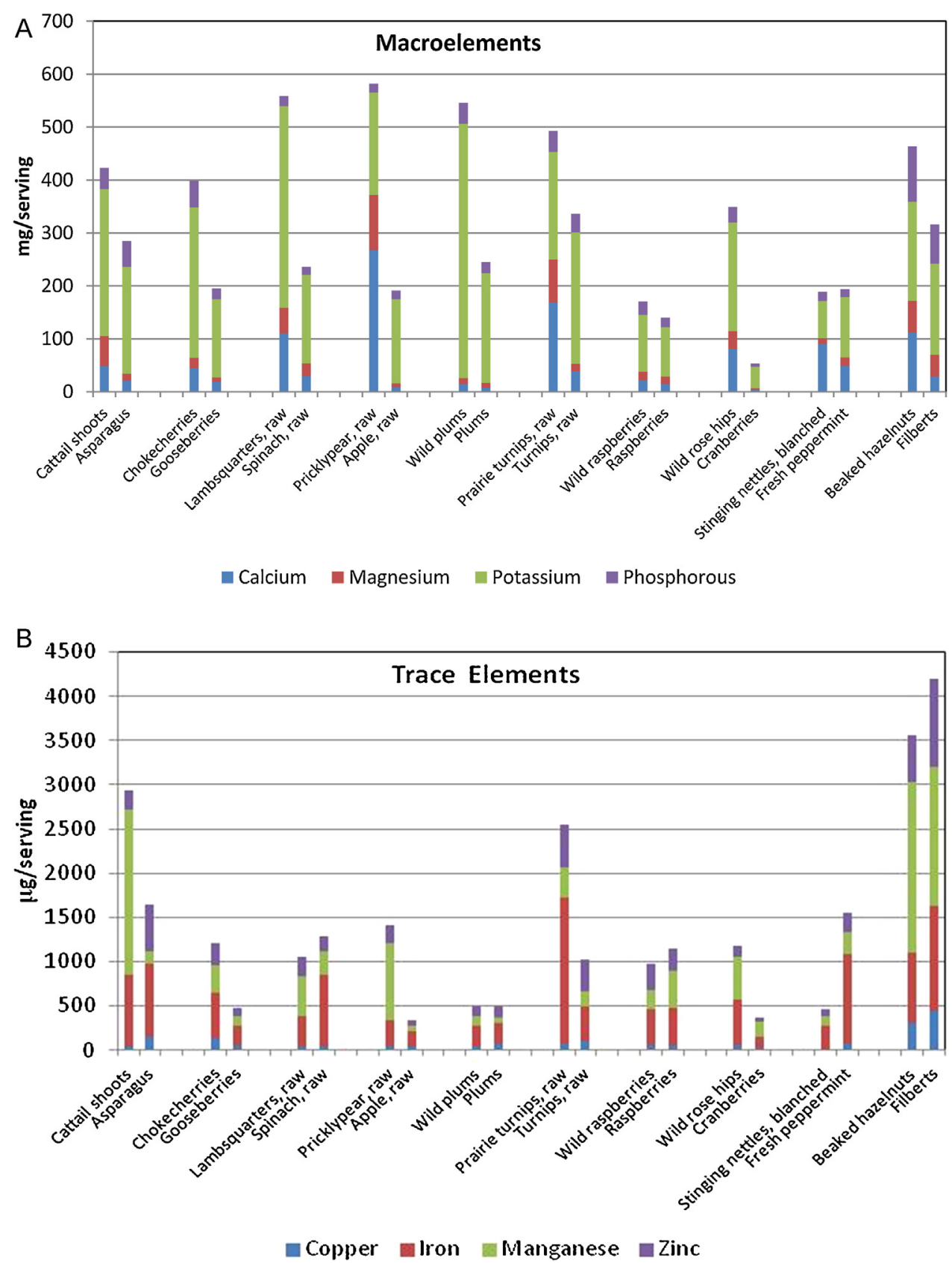

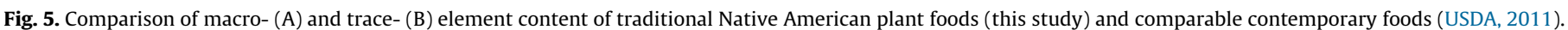
Serving sizes are given in Table 2.

Similarly, the carotenoid content of the traditional and contemporary foods could not be compared directly because the SR does not contain values for carotenoids in all of the contemporary foods. Although there have been literature reports on carotenoids in some of the species studied (e.g. Andersson et al., 2011; Guil-Guerrero et al., 2003; Kuhnlein, 1990; Raju et al., 2007; Uusiku et al., 2010), the studies were on different samples, possibly of different variety and/or produced under disparate growing conditions and/or postharvest handling, all of which can affect carotenoid production, as has been demonstrated for other plant foods (de Faria et al., 2009; Hejtmánková et al., 2013; Reif et al., 2013; Rodriguez-Amaya et al., 2008). Without common control samples, it is impossible to make comparisons between the carotenoid composition of different samples of the same food that was determined at other laboratories, since it would not thus be possible to distinguish analytical uncertainty from differences in composition. This study was focused specifically on composition of indigenous plants consumed by US Northern Plains native Americans. The results for the quality control samples (Table 8), many of which are commercially available reference materials, allow assessment of accuracy and a basis by which values can be compared between other studies that include the same reference material. The relatively high carotenoid concentrations in the traditional Native American plants (Table 8 and Fig. 3) suggest that inclusion of these foods in the diet would contribute significantly to carotenoid intake. No recommended intake for individual carotenoids exists, but some can be converted to vitamin A (IOM, 2000). 


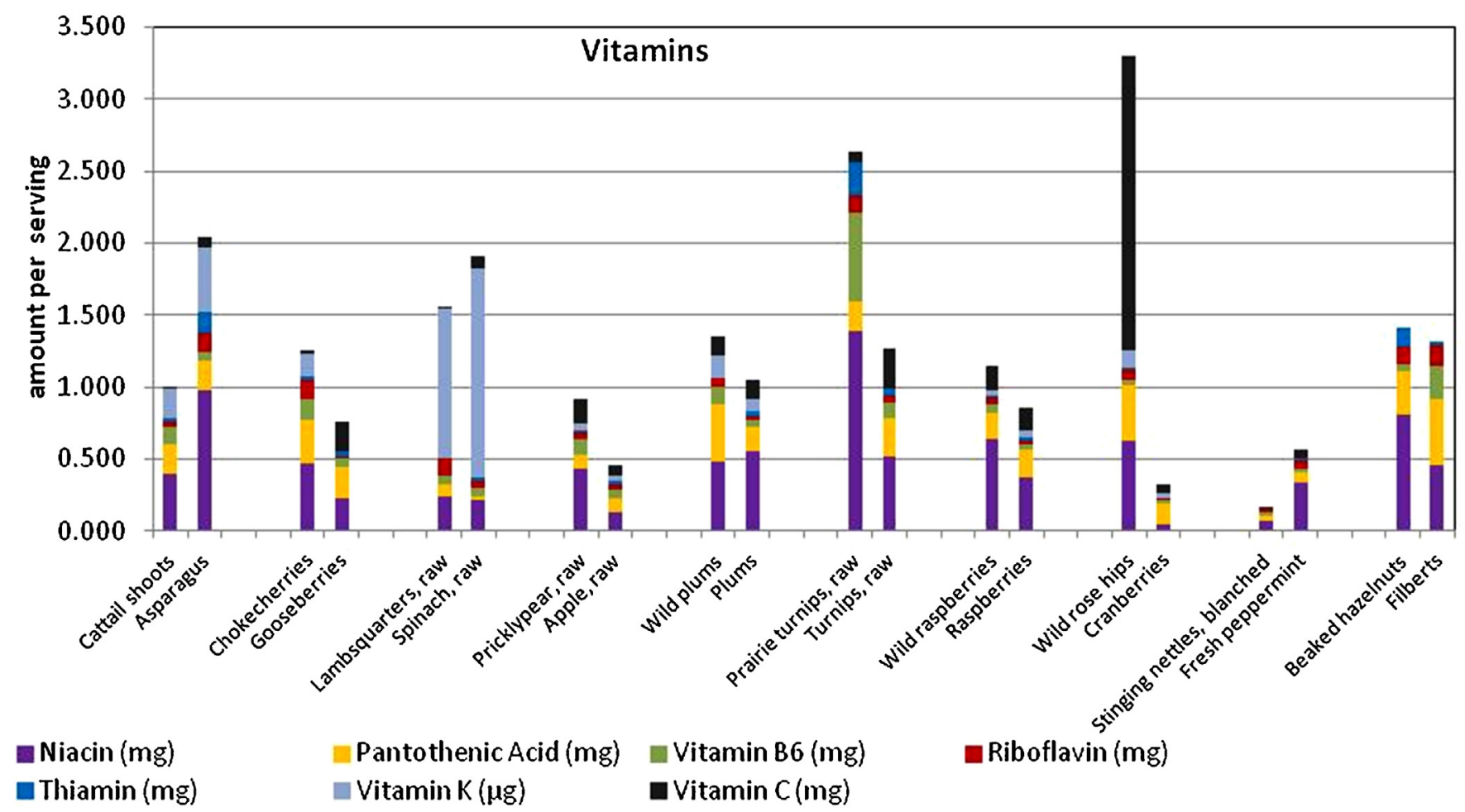

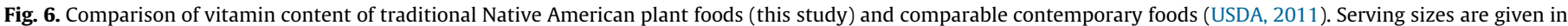
Table 2. (Data are not included for a nutrient and pair of foods when values were not determined in both foods.)

\section{Conclusions}

Consumption of wild plants, an important source of essential nutrients but for which data are limited, has declined among American Indians. The incidence of chronic disease has increased in US Native American Plains tribes in the last several generations along with a shift away from consumption of traditional foods (Conti, 2008; Taylor et al., 2005; Welty et al., 2002). Dietary interventions and recommendations that include increasing consumption of culturally relevant traditional foods have been promoted (Kattelmann et al., 2009; Holm et al., 2010; Jernigan et al., 2010; Schell and Gallo, 2012; Sinclair et al., 2011; Zephier et al., 1997). However, only limited data on the composition of indigenous plant foods exist. Moreover, Kuhnlein (2000), for example, has described the difficulties in collecting samples of traditional foods from native populations. The Native American Plains traditional plants analyzed in this study can potentially provide important nutrients to the diet of tribes of the region. For example, one serving of steamed lambsquarters, a rich source or many nutrients, contained more than $60 \%$ of the thiamin, $40 \%$ of the vitamin B6, $60 \%$ and $70 \%$ of the calcium and magnesium, respectively, and $10 \%$ of the potassium daily recommended intake (Institute of Medicine, 1997, 1998).

Recommendations to increase dietary calcium and magnesium to prevent cardiovascular diseases (Conti, 2008) support the consumption of plains prickly pears, prairie turnips, and beaked hazelnuts. Copper, which is highlighted to reduce the risk of stroke and heart attacks (Klevay, 2011), is appreciably high in beaked hazelnuts, lambsquarters, and chokecherries. Importantly, sodium, which is a risk factor for high blood pressure for which the recommended intake is generally exceeded in contemporary Native American populations (Stang et al., 2005) was low in all of the native plant foods (as well as the contemporary counterparts). Thus, these findings provide new evidence of the nutritional value of the traditional Native American plant foods. There have also been publications on the phytochemical composition and bioactivity of some of these foods (e.g. Budinsky et al., 2001; Burns Kraft et al., 2008; Hosseinian et al., 2007; Schauss, 2010), but further composition data would be valuable given the importance of bioactive non-nutrients such as procyanidins and flavanols (Bagchi et al., 2000; Ekström et al., 2011; Erdman et al., 2007; Lam et al., 2010; Schroeter et al., 2010).

It should be noted that nutrient content is not equivalent to bioavailability, and that antinutrients present in some foods may have an impact, depending on how the food is prepared. For example, oxalic acid has been reported in C. album L. (lambsquarters) in some studies, and this antinutrient could reduce the bioavailability of calcium (Guil et al., 1996, 1997). While it is not possible to discuss all aspects of potential antinutritional factors in a scientific report on nutrient composition of native plant foods, obviously any contraindications with respect to consumption of wild plants and any mitigation of those factors that might occur in different preparations (e.g. as described in Table 3 ) should be taken into consideration.

Data for these foods were incorporated into the USDA Nutrient Database for Standard Reference, release 20 (USDA, 2007) in a distinct food group, i.e. American Indian/Alaska Native foods (USDA, 2011). Additionally, this nutritional information has been shared with each participating tribe. It can be used by tribal leaders and dietitians in discussions of culturally appropriate dietary means to reduce risk of obesity, type 2 diabetes and cardiovascular diseases. A possible follow-up study is planned, if recommended by tribal leaders, that would examine the preparation of mixed meals composed of traditional plant and game foods to determine nutrient contents. This information would be shared with designated health-promotion groups at the participating reservations for use in community-based, participatory interventions to prevent obesity and diabetes among Native people. Finally, it is worth noting that many of these plants are often dried and preserved for year-round consumption and thus should be 
sampled and analyzed in those forms in future studies, given the effect of drying on nutrient content. With many tribes pursuing a return to traditional foods, additional analyses of other components, including phytochemicals and other nutrients in indigenous wild plants, are also warranted.

\section{Acknowledgements}

The authors would like to thank the following for their assistance in completing this project: Dr. David M. Gipp, President of United Tribes Technical College, United Tribes Technical College Tribal Land Grant Program staff; Doris Zidon; Amy Rasor and Nancy Conley (sample preparation); David Ruggio and Medhi Ashraf-Khorassani (folate analysis), and Maria Teresa TarragoTrani (vitamin C analysis).

\section{References}

Amy, L.A., Pehrsson, P.R., 2003. Development of the American Indian and Alaska native foods database: status report. Journal of the American Dietetic Association 103 (Suppl. 9), 55-56.

Andersson, S.C., Rumpunen, K., Johansson, E., Olsson, M.E., 2011. Carotenoid content and composition in rose hips (Rosa spp.) during ripening, determination of suitable maturity marker and implications for health promoting food products. Food Chemistry 128, 689-696.

AOAC, 2011. Official Methods of Analysis of the Association of Official Analytical Chemists. Association of Official Analytical Chemists, Washington, DC, USA Available from: http://www.eoma.aoac.org/ (accessed 21.12.11).

Bagchi, D., Bagchi, M., Stohs, J., Das, D.K., Ray, S.D., Kuszynski, C.A., Joshi, S.S., Pruess, H.G., 2000. Free radicals and grape seed proanthocyanidin extract: importance of human health and disease prevention. Toxicology 148, 187-197.

Bhargava, A., Shukla, S., Srivastava, J., Singh, N., Ohri, D., 2008. Genetic diversity for mineral accumulation in the foliage of Chenopodium spp. Scientia Horticulturae $118,338-346$

Bass, M., Wakefield, L., 1974. Nutrient intake and food patterns of Indians on Standing Rock Reservation. Journal of the American Dietetic Association 64, 36-41.

Booth, S.L., Sadowsi, J.A., 1997. Determination of phylloquinone in foods by high performance liquid chromatography. Methods in Enzymology 282, 446-456.

Budinsky, A., Wolfram, R., Oguogho, A., Efthimiou, Y., Stamatopoulos, Y., Sinzinger H., 2001. Regular ingestion of Opuntia robusta lowers oxidation injury. Prostaglandins, Leukotrienes, and Essential Fatty Acids 65, 45-50.

Burlingame, B., Charrondiere, R., Mouille, B., 2009. Food composition is fundamental to the cross-cutting initiative on biodiversity for food and nutrition. Journal of Food Composition and Analysis 22, 361-365.

Burns Kraft, T.F., Dey, M., Rogers, R.B., Ribnicky, D.M., Gipp, D.M., Cefalu, W.T. Raskin, I., Lila, M.A., 2008. Phytochemical composition and metabolic performance-enhancing activity of dietary berries traditionally used by Native North Americans. Journal Agricultural and Food Chemistry 56, 654-660.

Byers, T., 1996. Nutrition and cancer among American Indians and Alaska Natives. Cancer 78, 1612-1616

Charrondière, U.R., Stadlmayr, B., Rittenschober, D., Mouille, B., Nilsson, E., Medhammar, E., Olango, T., Eisenwagen, S., Persijn, D., Ebanks, K., Nowak, V., Du, J. Burlingame, B., 2013. FAO/INFOODS food composition database for biodiversity. Food Chemistry 140, 408-412.

Conti, K., 2008. Nutrition status of American Indian adults and impending needs in view of the Strong Heart Dietary Study. Journal of the American Dietetic Association 108, 781-784.

Craft, N.E., 2001. Chromatographic techniques for carotenoid separation. In: Wrolstad, R.E., Acree, T.E., An, H., Decker, E.A., Penner, M.H., Reid, D.S., Schwartz, S.J. Shoemaker, C.F., Sporns, P. (Eds.), Current Protocols in Food Analytical Chemistry. John Wiley \& Sons, New York, NY, USA, pp. F2.3.1-F2.3.15.

deGonzague, B., Receveur, O., Wedll, D., Kuhnlein, H.V., 1999. Dietary intake and body mass index of adults in 2 Ojibwe communities. Journal of the American Dietetic Association 99, 710-716.

Ekström, A.M., Serafini, M., Nyren, O., Wolk, A., Bosetti, C., Belloco, R., 2011. Dietary quercetin and risk of gastric cancer: results from a population-based study in Sweden. Annals of Oncology 22, 438-443.

Erdman, J.W., Balentine, D., Arab, L., Beecher, G., Dwyer, J.T., Folts, J., Harnly, J., Hollman, P., Keen, C.L., Mazza, G., et al., 2007. Flavonoids and heart health: proceedings of the ILSI North America flavonoids workshop. Journal of Nutrition 137, 718S-737S.

Ershow, A.G., 2003. Research science, regulatory science, and nutrient databases: achieving an optimal convergence. Journal of Food Composition and Analysis $16,255-268$

de Faria, A.F., Hasegawa, P.N., Chagas, E.A., Pio, R., Purgatto, E., Mercadante, A.Z., 2009. Cultivar influence on carotenoid composition of loquats from Brazil. Journal of Food Composition and Analysis 22, 196-203.

Finglas, P.M., Scott, K.J., Witthöft, C.M., van den Berg, H., de Froidmont-Görtz, I., 1998. The certification of the mass fractions of vitamins in four reference materials: wholemeal flour (CRM 121), milk powder (CRM 421), lyophilized mixed vegetables (CRM 485), and lyophilized pigs liver (CRM 487). EUR Report 18320. Office for Official Publications of the European Communities, Luxembourg, Belgium.

Gilbody, S., Lewis, S., Lightfoot, T., 2007. Methylenetetrahydrofolate reductase (MTHFR) genetic polymorphisms and psychiatric disorders: a HuGE review. American Journal of Epidemiology 165, 1-13.

Gilmore, M.R., 1991. Uses of Plants by the Indians of the Missouri River Region. University of Nebraska Press, Lincoln, NE, USA.

Guil, J.L., Torija, M.E., Giménez, J.J., Rodríguez-García, I., Giménez, A., 1996. Oxalic acid and calcium determination in wild edible plants. Journal of Agricultural and Food Chemistry 44, 1821-1823.

Guil, J.L., Rodríguez-García, I., Torija, E., 1997. Nutritional and toxic factors in selected wild edible plants. Plant Foods for Human Nutrition 51, 99-107.

Guil-Guerrero, J.L., Rebolloso-Fuentes, M.M., Isasa, M.E., 2003. Fatty acids and carotenoids from stinging nettle (Urtica dioica L.). Journal of Food Composition and Analysis 16, 111-119.

Haytowitz, D.B., Pehrsson, P.R., Holden, J.M., 2008. The National Food and Analysis Program: a decade of progress. Journal of Food Composition and Analysis 21, S94-S102.

Hejtmánková, K., Kotíková, Z., Hamouz, K., Pivec, V., Vacek, J., Lachman, J., 2013. Influence of flesh colour, year and growing area on carotenoid and anthocyanin content in potato tubers. Journal of Food Composition and Analysis 32, 20-27.

Heywood, V.H., 2011. Ethnopharmacology, food production, nutrition and biodiversity conservation: towards a sustainable future for indigenous peoples. Ethnopharmacology biodiversity_food composition. Journal of Ethnopharmacology 137, 1-15.

Holm, J.E., Vogeltanz-Holm, N., Poltavski, D., McDonald, L., 2010. Assessing health status, behavioral risks, and health disparities in American Indians living on the northern plains of the US. Public Health Reports 125, 68-78.

Hosseinian, F.S., Li, W., Hydamaka, A.W., Tsopmo, A., Lowry, L., Friel, J., Beta, T., 2007. Proanthocyanidin profile and ORAC values of Manitoba berries, chokecherries, and seabuckthorn. Journal of Agricultural and Food Chemistry 55, 6970-6976.

Institute of Medicine, Food and Nutrition Board, 1997. Dietary Reference Intakes: Calcium, Phosphorus, Magnesium, Vitamin D, and Fluoride. National Academy Press, Washington, DC, USA.

Institute of Medicine, Food and Nutrition Board, 1998. Dietary Reference Intakes for Thiamin, Riboflavin, Niacin, Vitamin $\mathrm{B}_{6}$, Folate, Vitamin $\mathrm{B}_{12}$, Pantothenic Acid, Biotin, and Choline. National Academy Press, Washington, DC, USA.

Institute of Medicine, Food and Nutrition Board, 2000. Dietary Reference Intakes for Vitamin C, Vitamin E, Selenium, and Carotenoids. National Academy Press, Washington, DC, USA.

Institute of Medicine, Food and Nutrition Board, 2001. Dietary Reference Intakes for Vitamin A, Vitamin K, Arsenic, Boron, Chromium, Copper, Iodine, Iron, Manganese, Molybdenum, Nickel, Silicon, Vanadium, and Zinc. National Academy Press, Washington, DC, USA.

Institute of Medicine, Food and Nutrition Board, 2002. Dietary Reference Intakes for Energy, Carbohydrate, Fiber, Fat, Fatty Acids, Cholesterol, Protein, and Amino Acids (Macronutrients). National Academy Press, Washington, DC, USA.

Institute of Medicine, Food and Nutrition Board, 2004. Dietary Reference Intakes For Water, Potassium, Sodium, Chloride, and Sulfate. National Academy Press, Washington, DC, USA.

Institute of Medicine (US), 2011. Committee to review dietary reference intakes for vitamin D and calcium. In: Ross, A.C., Taylor, C.L., Yaktine, A.L. (Eds.), Dietary Reference Intakes for Calcium and Vitamin D. National Academies Press, Washington, DC, USA.

Jernigan, V.B.B., Duran, B., Ahn, D., Winkleby, M., 2010. Changing patterns in health behaviors and risk factors related to cardiovascular disease among American Indians and Alaska natives. American Journal of Public Health 100, 677-683.

Kattelmann, K.K., Conti, K., Ren, C., 2009. The medicine wheel nutrition intervention: a diabetes education study with the Cheyenne River Sioux Tribe. Journal of the American Dietetic Association 109, 1532-1539.

Kittler, P.G., Sucher, K.P., 2001. Food and Culture, 3rd ed. Wadsworth/Thomson Learning, Belmont, CA, USA pp. 94, 496.

Klevay, L.M., 2011. Is the Western diet adequate in copper? Journal of Trace Elements in Medicine and Biology 25, 204-212

Koc, H., Mar, M.-H., Ranasinghe, A., Swenberg, J.A., Zeisel, S.H., 2002. Quantitation of choline and its metabolites in tissues and foods by liquid chromatography/ electrospray ionization-isotope dilution mass spectrometry. Analytical Chemistry $74,4734-4740$.

Koontz, J.L., Phillips, K.M., Wunderlich, K.M., Exler, J., Holden, J.M., Gebhardt, S.E. Haytowitz, D.B., 2005. Comparison of total folate concentration in foods determined by microbiological assay at several experienced laboratories. Journal of the Association of Official Analytical Chemists International 88, 805-813.

Kuhnlein, H.V., 1990. Nutrient values in indigenous wild plant greens and roots used by the Nuxalk people of Bella Coola, British Columbia. Journal of Food Composition and Analysis 3, 38-46.

Kuhnlein, H.V., 2000. The joys and pains of sampling and analysis of traditional food of indigenous peoples. Journal of Food Composition and Analysis 13, 649-658.

Lam, T.K., Rotunno, M., Lubin, J.H., Wacholder, S., Consonni, D., Pesatori, A.C., Bertazzi, P.A., Chanock, S.J., Burdette, L., Goldstein, A.M., et al., 2010. Dietary quercetin, quercetin-gene interaction, metabolic gene expression in lung tissue and lung cancer risk. Carcinogenesis 31, 634-642.

Li, G.-M., Presnell, S.R., Gu, L., 2003. Folate deficiency, mismatch repair-dependent apoptosis, and human disease. Journal of Nutritional Biochemistry 14, 568-575. 
Lytle, L., Dixon, L., Cunningham-Sabo, L., Evans, M., Gittelsohn, J., Hurley, J., Snyder, P., Stevens, J., Weber, J., Anliker, J., Heller, K., Story, M., 2002. Dietary intakes of Native American children: findings from the Pathways Feasibility Study. Journal of the American Dietetic Association 102, 555-559.

Merrill, A.L., Watt, B.K., 1973. Energy value of foods...basis and derivation. In: United States Department of Agriculture Handbook No. 74. U.S. Government Printing Office, Washington, DC.

Moat, S.J., Lang, D., McDowell, I.F.W., Clarke, Z.L., Madhavan, A.K., Lewis, M.J., Goodfellow, J., 2004. Folate, homocysteine, endothelial function and cardiovascular disease. Journal of Nutritional Biochemistry 15, 64-79.

Pennington, J.A.T., 2003. National Institutes of Health (NIH) activities concerning nutrition research related to food composition databases. Journal of Food Composition and Analysis 16, 359-364.

Pennington, J.A.T., 2008. Applications of food composition data: data sources and use. Journal of Food Composition and Analysis 21, S3-S12.

Phillips, K.M., Patterson, K.Y., Rasor, A.R., Exler, J., Haytowitz, D.M., Holden, J.M., Pehrsson, P.R., 2006a. The role of quality control and reference materials in the National Food and Nutrient Analysis Program. Analytical and Bioanalytical Chemistry 384, 1341-1355.

Phillips, K.M., Ruggio, D.M., Ashraf-Khorassani, M., Haytowitz, D.B., 2006b. Difference in folate content of green and red sweet peppers (Capsicum annuum) determined by liquid chromatography-mass spectrometry. Journal of Agricultural and Food Chemistry 54, 9998-10002.

Phillips, K.M., Patterson, K.Y., Wolf, W.R., Sharpless, K.E., Holden, J.M., 2007. Reference materials to evaluate measurement systems for the nutrient composition of foods: results from USDA's National Food and Nutrient Analysis Program. Analytical and Bioanalytical Chemistry 389, 219-229.

Powers, W.K., Powers, M.N., 1990. Sacred Foods of the Lakota. Lakota Books, Kendall Park, NJ, USA.

Rao, A.V., Rao, L.G., 2007. Carotenoids and human health. Pharmacological Research 55, 207-216.

Raju, M., Varakumar, S., Lakshminarayana, R., Krishnakantha, T.P., Baskaran, V., 2007. Carotenoid composition and vitamin A activity of medicinally important green leafy vegetables. Food Chemistry 101, 1598-1605.

Reamer, D.C., Veillon, C., 1981. Determination of selenium in biological materials by stable isotope dilution gas chromatography-mass spectrometry. Analytical Chemistry 53, 2166-2169.

Reif, C., Arrigoni, E., Berger, F., Baumgartner, D., Nyström, L., 2013. Lutein and $\beta$ carotene content of green leafy Brassica species grown under different conditions. LWT - Food Science and Technology 53, 378-381.

Robien, K., Ulrich, C.M., 2003. 5,10-Methylenetetrahydrofolate reductase polymorphisms and leukemia risk: a HuGE minireview. American Journal of Epidemiology 157, 571-582.

Rodriguez-Amaya, D.B., Kimura, M., Godoy, H.T., Amaya-Farfan, J., 2008. Updated Brazilian database on food carotenoids: factors affecting carotenoid composition. Journal of Food Composition and Analysis 21, 445-463.

Schauss, A.G., 2010. Emerging knowledge of the bioactivity of foods in the diets of indigenous North Americans. In: Watson, R.R., Preedy, V.R. (Eds.), Bioactive Foods in Promoting Health - Fruits and Vegetables. Academic Press, New York, NY, USA, pp. 71-84,

Schell, L.M., Gallo, M.V., 2012. Overweight and obesity among North American Indian infants, children, and youth. American Journal of Human Biology 24, 302-313.

Schroeter, H., Heiss, C., Spencer, J.P.E., Keen, C.L., Lupton, J.R., Schmitz, H.H., 2010 Recommending flavanols and procyanidins for cardiovascular health: current knowledge and future needs. Molecular Aspects of Medicine 31, 546-557.
Sinclair, K.A., Bogart, A., Buchwald, D., Henderson, J.A., 2011. The prevalence of metabolic syndrome and associated risk factors in Northern Plains and Southwest American Indians. Diabetes Care 34, 118-120.

Stang, J., Zephier, E.M., Story, M., Himes, J.H., Yeh, J.L., Welty, T., Howard, B.V., et al., 2005. Dietary intakes of nutrients thought to modify cardiovascular risk from three groups of American Indians: the Strong Heart Dietary Study, Phase II Journal of the American Dietetic Association 105, 1895-1903.

Story, M., Strauss, K., Zephier, E., Broussard, B., 1998. Nutritional concerns in American Indians and Alaska Native children: transitions and future direction. Journal of the American Dietetic Association 98, 170-176.

Tarrago-Trani, M.T., Phillips, K.M., Cotty, M., 2012. Matrix-specific method validation for quantitative analysis of vitamin $\mathrm{C}$ in diverse foods. Journal of Food Composition and Analysis 26, 12-25.

Taylor, C.A., Keim, K.S., Gilmore, A.C., 2005. Impact of core and secondary foods on nutritional composition of diets in Native-American women. Journal of the American Dietetic Association 105, 413-419.

Toledo, A., Burlingame, B., 2006. Biodiversity and nutrition: a common path toward global food security and sustainable development. Journal of Food Composition and Analysis 19, 477-483.

Toma, R.B., Curry, M.L., 1980. North Dakota Indians' traditional foods. Journal of the American Dietetic Association 76, 589-590.

Topping, D.L., 2013. Dietary fiber: physiological effects and health outcomes. In: Caballero, B. (Ed.), Encyclopedia of Human Nutrition. 3rd ed. Academic Press, Waltham, MA, USA, pp. 50-54.

Trainer, D., Pehrsson, P.R., Haytowitz, D.B., Holden, J.M., Phillips, K.M., Rasor, A.S. Conley, N.A., 2010. Development of sample handling procedures for foods under USDA's National Food and Nutrient Analysis Program. Journal of Food Composition and Analysis 23, 43-851.

USDA, Agricultural Research Service, 2007. USDA Nutrient Database for Standard Reference, Release 20. United States Department of Agriculture, Beltsville, $\mathrm{MD}$, USA.

USDA, Agricultural Research Service, 2011. USDA Nutrient Database for Standard Reference, Release 24. United States Department of Agriculture, Beltsville, MD, USA. http://www.nal.usda.gov/fnic/foodcomp/search/

USDA Natural Resources Conservation Service, 2013. The PLANTS Database. USDA National Plant Data Team, Greensboro, NC, USA. http://plants.usda.gov.

US Pharmacopeial Convention (USP), 1995. US Pharmacopeia, 23rd revision. USP. Rockville, MD, USA, pp. 257-258.

Uusiku, N.P., Oelofse, A., Duodu, K.G., Bester, M.J., Faber, M., 2010. Nutritional value of leafy vegetables of sub-Saharan Africa and their potential contribution to human health: a review. Journal of Food Composition and Analysis 23, 499-509.

Welty, T.K., Rhoades, D.A., Yeh, F., Lee, E.T., Cowan, L.D., Fabsitz, R.R., Robbins, D.C., Devereux, R.B., Henderson, J.A., Howard, B., 2002. Changes in cardiovascular disease risk factors among American Indians. The Strong Heart Study. Annals of Epidemiology 12, 97-106.

Woolf, N., Conti, K.M., Johnson, C., Martinez, V., McCloud, J., Zephier, E.M., 1999 Northern Plains Indian Food Practices, Customs and Holidays. Ethnic and Regional Food Practices-A Series. American Dietetic Association, Chicago, IL, USA.

Yildirim, E., Dursun, A., Turan, M., 2001. Determination of the nutrition contents of the wild plants used as vegetables in Upper Coruh Valley. Turkish Journal of Botany 25, 367-371.

Zephier, E.M., Ballew, C., Mokdad, A., Mendlein, J., Smith, C., Yeh, J.L., Lee, E., Welty, T.K., Howard, B., 1997. Intake of nutrients related to cardiovascular disease risk among three groups of American Indians: the Strong Heart Study. Preventive Medicine 26, 508-515. 